\title{
LENDING TO THE BORROWER FROM HELL: DEBT AND DEFAULT IN THE AGE OF PHILIP II, 1556-1598*
}

\author{
Mauricio Drelichman \\ The University of British Columbia \\ and \\ CIFAR
}

\author{
Hans-Joachim Voth \\ ICREA/Universitat Pompeu Fabra \\ and \\ CREI
}

First Draft: December 2007

This Draft: December 2008

\begin{abstract}
Philip II of Spain accumulated debts equivalent to $60 \%$ of GDP. He also failed to honor them four times. We ask what allowed the sovereign to borrow much while defaulting often. Earlier work emphasized either banker irrationality or the importance of sanctions. Using new archival data, we show that neither interpretation is supported by the evidence. What sustained lending was the ability of bankers to cut off Philip II's access to smoothing services. We analyze the incentive structure that supported the cohesion of this bankers' coalition. Lending moratoria were sustained through a "cheat the cheater" mechanism (Kletzer and Wright, 2000).
\end{abstract}

\footnotetext{
"We thank Carlos Alvarez Nogal, Fernando Broner, Michael Burda, Ann Carlos, Sir John Elliott, Oscar Gelderblom, Phil Hoffman, Hugo Hopenhayn, Ken Kletzer, Michael Kremer, Andreu Mas-Colell, Leandro Prados de la Escosura, Emilia Simeonova, Chris Sims, Jaume Ventura, Mark Wright, and Jeromin Zettelmeyer as well as seminar participants at Caltech, Stanford, UC Berkeley, UC Davis, Universidad Carlos III, UBC, Humboldt University, UPF, the 2008 Canadian Network for Economic History Conference, the CREI-CEPR Conference on Sovereign Risk, the Finance and History Conference at the University of Utrecht, and the History of Public Finances workshop at the Paris School of Economics. We also thank Marcos Agurto, Hans-Christian Boy, Diego Pereira Garmendía, Germán Pupato, Javier Torres, Cristian Troncoso-Valverde, and Anthony Wray for research assistance. Financial support from SSHRCC, TARGET/INE, the Spanish Ministry of Education, CREA, and a UBC AURA award is gratefully acknowledged.
} 


\section{Introduction}

What sustains international borrowing by sovereigns? One important school of thought argues that, in the absence of borrower commitment, punishment mechanisms outside the lending transaction itself are necessary to make international lending to governments sustainable. ${ }^{1}$ Other authors have emphasized the importance of reputation and the need for intertemporal smoothing. ${ }^{2}$ A recent literature focuses on the importance of coordination, incentive structures, and market power between lenders (Kletzer and Wright 2000; Wright 2002; Kovrijnykh and Szentes 2007). ${ }^{3}$ In this paper, we examine one of the most famous historical cases at the dawn of sovereign borrowing in an attempt to decide which mechanism was responsible for sustained lending.

Philip II ruled from 1556 to 1598. During his reign, the Spanish Empire was at the height of its power. Spain fought numerous wars against France, the Dutch rebels, the English, and the Ottomans. It conquered the Philippines and acquired Portugal and its overseas possessions. Earlier princes had borrowed abroad, but Philip II was the first to accumulate foreign debts similar to those of modern states, borrowing approximately $60 \%$ of national product. He also became the first serial defaulter in history, declaring payment stops no less than four times during his reign. Eventually, Spain went on to become the record holder for repeated defaults, reneging no fewer than 13 times on its obligations. ${ }^{4}$ We ask how the king could accumulate massive debts while defaulting so often.

Two explanations for lending to Philip II stand out in the historical literature: lender irrationality and the ability of bankers to punish the king. Braudel (1966) famously argued that the king skillfully played off one group of bankers against the other, defaulting on each in turn while making promises he could not keep. ${ }^{5}$ To this day, journalists use the bankruptcies of Castile under Philip as potent symbols of banker irrationality. ${ }^{6}$ In contrast, Conklin (1998) concluded that the Genoese bankers had an

\footnotetext{
${ }^{1}$ Bulow and Rogoff (1989a); Fernandez and Rosenthal (1990).

${ }^{2}$ Eaton and Fernandez (1995); Eaton and Gersovitz (1981).

${ }^{3}$ A third school of thought argues that reputation matters for interactions outside the credit market itself (Cole and Kehoe 1995).

${ }^{4}$ Braudel (1966); Reinhart, Rogoff, and Savastano (2003).

${ }^{5}$ In a similar spirit, Reinhart and Rogoff (2008) argue that swings in lender sentiment have often been responsible for boom-and-bust cycles in international lending.

${ }^{6}$ The Economist, 23-29 September 2006.
} 
effective punishment technology. Philip's war machine relied on massive transfers of funds from Castile to the front in Flanders. When Philip defaulted in 1575, the bankers stopped all transfers. The resulting sharp setbacks to Spain's military position forced the king to settle.

We use a new and comprehensive data set collected from archival sources to examine what underpinned lending. Based on data from 438 loan contracts from the General Archive in Simancas, we first show that neither lender sentiment nor sanctions can explain lending. The same banking families lent to Philip across the default episodes, which proves that they did not go bankrupt as a result of the payment stops. It also suggests that they were not dramatically disappointed by the defaults. There is also no evidence that Conklin's "transfer stop" was ever effective. Instead, we argue that incumbent bankers formed a de facto coalition with substantial market power that derived from a unique form of syndicated lending. Philip II's Genoese bankers provided two thirds of total (short-term) lending. They did so in overlapping partnerships, often extending loans jointly with other bankers who in turn may have already made multiple loans with other partners. We argue that this lending structure was crucial for the cohesion of the coalition. Genoese lenders to the Spanish Crown thus carefully structured a web of multilateral obligations that included joint loans, the cross-posting of collateral, and delegated collection of principal and interest. Connections transcended the lending business and involved help in court cases, intermarriage, and political cooperation in Genoa itself. This tightly knit community of bankers thus cooperated closely and acted as one at times when it mattered most—during the defaults.

When the coalition imposed a lending moratorium during a period when the king did not pay, the Crown was unable to borrow. No network members broke rank; no preexisting lender from outside the network lent; and no banker entered into a new lending relationship with the king. The reason is that any bankers who "cheated" by lending during the moratorium would face severe penalties. These took different forms for network members versus outsiders. Network members could hurt each other financially in numerous ways - for example, by seizing cross-posted collateral or failing to make payments due. Social sanctions were also available. In addition, both network members and outsiders faced what Kletzer and Wright (2000) called "cheat the cheater" incentives, 
which punish the noncooperative lender more indirectly. Because of the massive cost of wars, the king's borrowing needs were large. He would therefore have to settle with the Genoese coalition eventually. The king had every incentive to default on lenders who offered funds during a payment stop. Based on their size and previous relationship, network lenders could always offer a better deal to the king. Using evidence from the correspondence of German bankers who considered lending during the Genoese moratorium, we argue that the "cheat the cheater" mechanism was an effective deterrent to new entry.

Faced with volatile revenues, urgent spending needs, and a total cessation of lending, the king quickly came to an agreement with his creditors. We conclude that the need for intertemporal smoothing, combined with lenders' market power, was sufficient to sustain lending. In this sense, our findings suggest that - in an environment without commitment, such as the one faced by lenders in 16th-century Spain - reputation-based models of sovereign borrowing can explain much of the behavior we observe. Similar to the Maghribi traders' coalition analyzed by Greif (1993), the Genoese network's cohesion and market power was sufficient to solve major agency problems. Despite the frequent fiscal crises of 16th-century Castile and the Spanish king's sweeping powers, private contractual arrangements underpinned borrowing that was comparable in magnitude, relative to GDP, to that of many OECD countries today.

Our work relates to the large literature on the sustainability of sovereign debt and on serial default. The pre-conditions for international lending were examined by Bulow and Rogoff (1989b), and contracting in an environment without commitment was analyzed in Bulow and Rogoff (1989a). Their work has received support from historical studies emphasizing the importance of punishment (Mitchener and Weidenmier 2005). In contrast to the implications of the sanctions literature, Eaton and Gersovitz (1981) argued that smoothing needs alone can enable countries to borrow up to a debt ceiling. This argument has received support from recent historical work by Tomz (2007). The importance of lender coordination and incentives in the spirit of Kletzer and Wright (2000), Wright (2002), and Kovrijnykh and Szentes (2007) is in line with the finding by Esteves (2006) that 19th-century bondholders' associations acted as effective conduits for renegotiation. 
The paper proceeds as follows. Section II summarizes the historical background and fiscal context of Philip II's debts, and Section III describes our data and its limitations. Section IV shows why neither banker turnover nor a "transfer stop" are appropriate interpretations of what sustained lending. We then analyze the structure of the market for lending to the Spanish Crown, illustrate the operation of the bankers' coalition, and show how it satisfied the conditions for incentive compatibility outlined by the modern literature. Section V concludes.

\section{Historical Background}

War in early modern Europe was costly. States spent more on armies and fleets than on any other activity, and few princes allocated more funds to war than Philip II. He was fighting a war every single year of his reign. ${ }^{7}$ Military expenditures accounted for more than $60 \%$ of the Spanish Crown's spending in the second half of the 16 th century. ${ }^{8}$ Success required the resources to maintain large armed forces for extended periods, often in distant theatres of war. Moreover, once a conflict attained a high level of intensity, expenditures also needed to be continuous if a ruler was to prevail. Therefore, given the belligerent nature of international politics in early modern Europe, states needed the ability to ramp up spending quickly and to sustain it for long periods.

Early modern fiscal systems were not well suited to this task. The bulk of the Crown's income came from sales taxes and contributions collected through the Church. The collection of these taxes was either farmed out to private collectors or delegated to cities in exchange for fixed yearly payments. Income was largely stable. However, one of the fastest-growing and most substantial sources of income for the Crown-revenues from the Indies - was highly variable. The main source of this revenue was a $20 \%$ tax on all silver imports from the New World. With the discovery of the rich silver mines of Potosi in the mid-1540s, these imports surged in volume, reaching peaks in excess of $40 \%$ of Crown income in several years in the 1580s and 1590s. During Philip's reign, on average one ducat of every five in revenue came from the Indies.

\footnotetext{
${ }^{7}$ Parker (1998, p. 2). During Philip II's reign of 42 years, Castile was at peace for a total of six months.

${ }^{8}$ Drelichman and Voth (2007).
} 


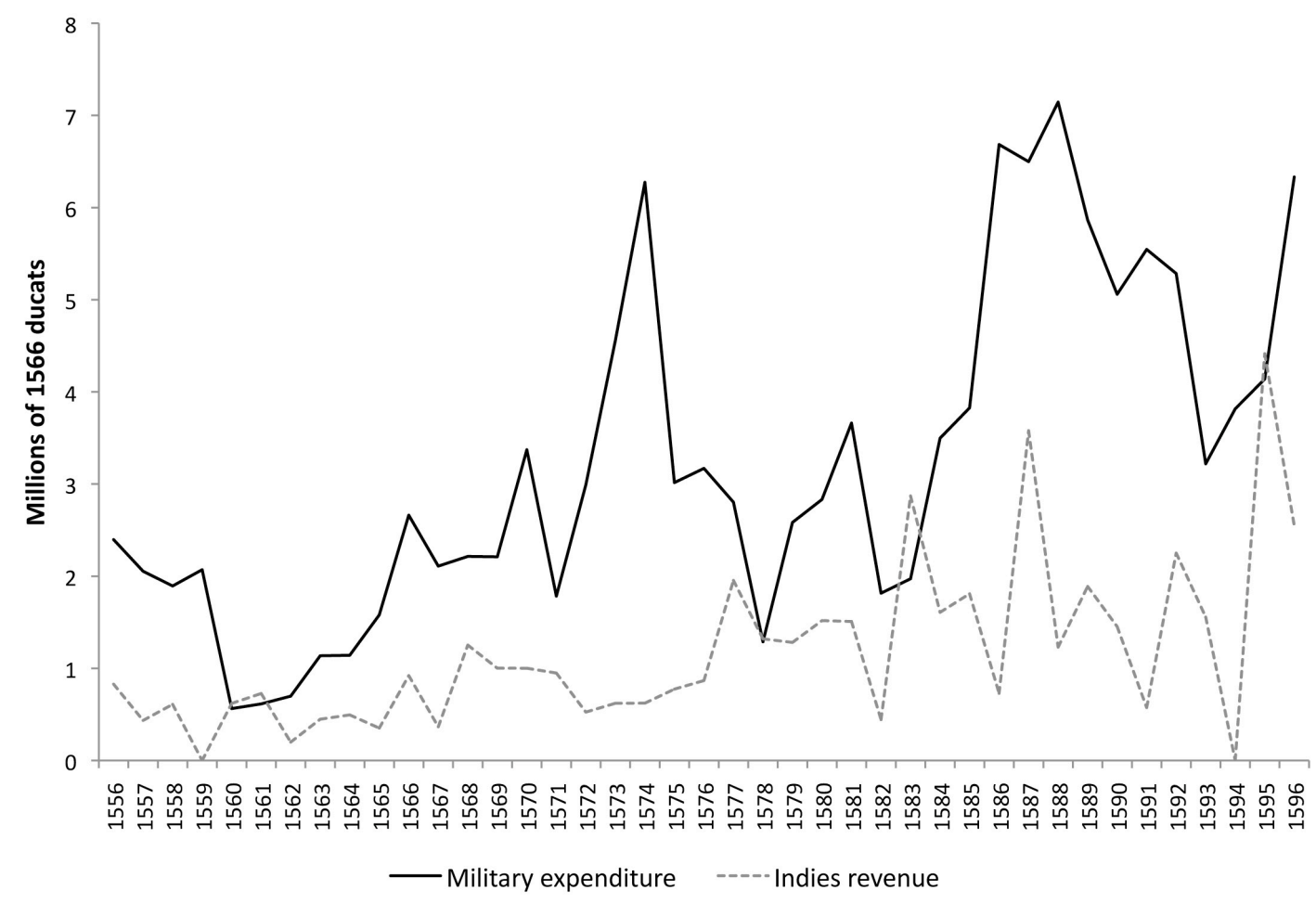

Figure 1: Military expenditure and Indies revenue

Silver shipments varied considerably from year to year as a result of conditions at the mines in Peru and the vagaries of Caribbean weather. The dashed line in Figure 1 shows the evolution of silver revenue. Large-scale borrowing helped to sustain expenditures, which could also vary markedly from year to year. Borrowing took two forms: long-term debt in the form of perpetual bonds (juros) and short-term loan contracts provided by bankers (asientos). Many asientos were eventually converted or refinanced through juros. While outstanding debt increased by 20.7 million constant 1565 ducats in the period between 1566 and 1600, the king entered into short-term contracts for 83.2 million ducats. ${ }^{9}$ In an average year, he contracted short-term loans for 2.5 million ducats, carried total outstanding debts of 34.9 million, and had revenues of 6.6 million. Figure 2 provides

\footnotetext{
${ }^{9}$ The ducat was a unit of account whose value in terms of silver did not change during the 16th century. The enormous output of the American silver mines, however, meant that silver itself was losing value. The Castilian price index rose by 53\% between 1566 and 1600. Unless otherwise specified, figures in this paper are reported in constant 1566 ducats, deflated using the price index for Old Castile (see Drelichman 2005).
} 
an overview of the king's fiscal position. ${ }^{10}$ Revenues and debts were both growing strongly during the second half of the 16th century.

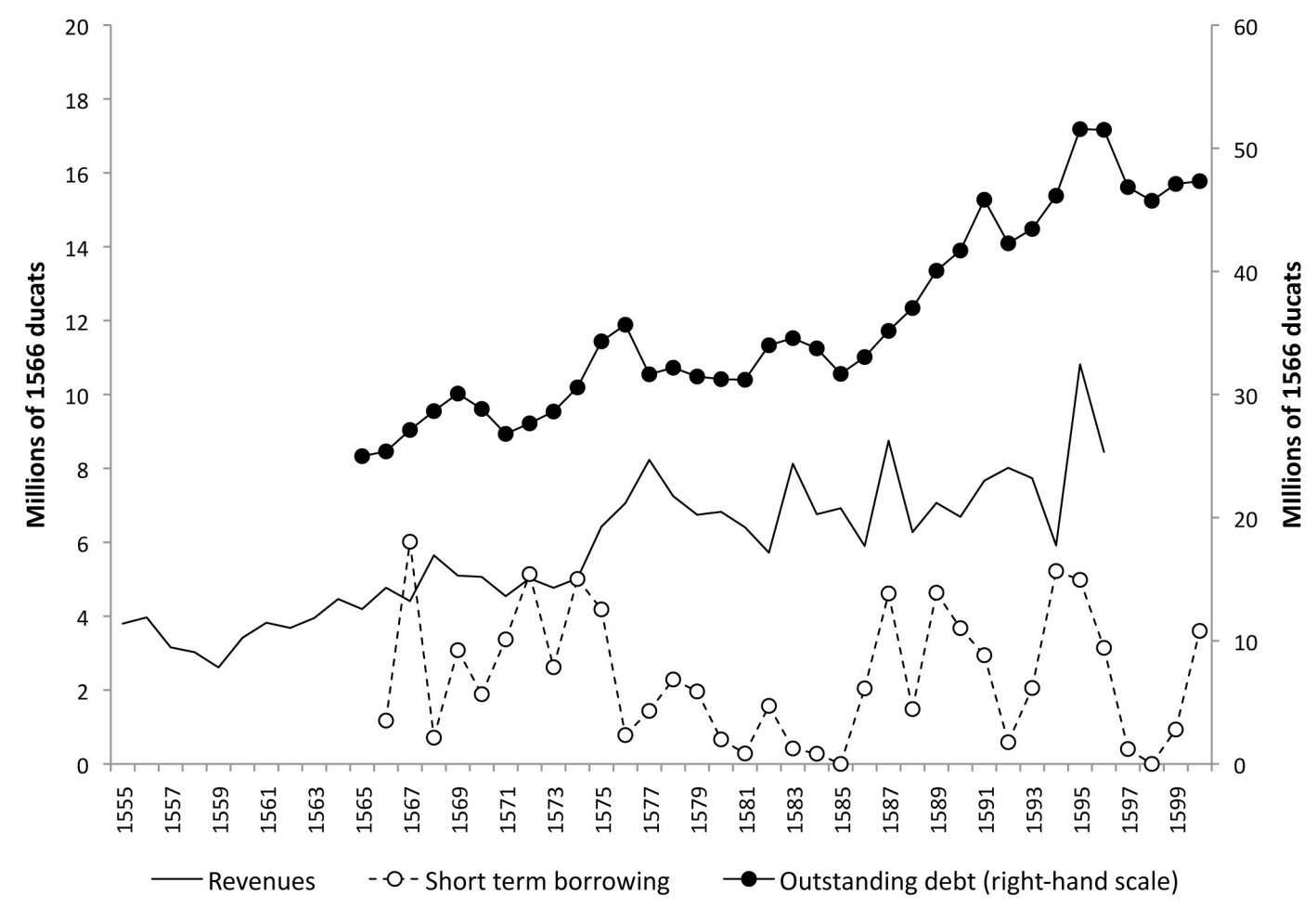

Figure 2: Castile's fiscal position, 1555-1600

Asientos were issued against the general credit of the king, not against a specific tax stream. ${ }^{11}$ In some cases, they formalized loan agreements struck by field commanders with bankers, which would then be sent back to Madrid. In general, they were used to fill in a funding gap at a critical point in time, such as during a spike in military expenditures. Long-term bonds (juros) accounted for a large share of Crown debt at any given moment in time. These were secured by regular taxes and other recurring forms of revenue, as authorized by the Cortes (the representative assembly of the Castilian cities). ${ }^{12}$ Juros were serviced only as long as the tax stream backing them generated sufficient funds. Information about the health of a tax stream was therefore of great importance. From

\footnotetext{
${ }^{10}$ Figures are from Drelichman and Voth (2007). Revenue data are available from 1555-1596; all other series are from 1566-1600. All the summary figures we give refer to the 1566-1596 period.

${ }^{11}$ There are exceptions to this, which we discuss in what follows.

${ }^{12}$ Juros could be issued only against "ordinary" (as opposed to "extraordinary") revenues. The classification of revenues was largely a matter of political bargaining between the king and the Cortes. Highly unstable revenues, such as remittances from the Indies, were not considered "ordinary" revenues and hence could not be securitized; see Toboso Sánchez (1987).
} 
1560 on, the Genoese specialized in acquiring information about the health of the fiscal streams backing juros. ${ }^{13}$

Although bankers like the Genoese principally lent short-term, they also placed juros for the Crown. Long-term bonds were often used as collateral for the new asientos. In most of these contracts, the king had the option not to repay the asiento in cash, in which case the banker could sell the juros. Because of the logistical difficulty of placing long-term debt directly, the king exercised this option frequently, making the Genoese key intermediaries in the bond market. Between 1560 and 1565, the Crown placed some 6 million ducats' worth of juros, of which 3.6 million were handled by the Genoese. ${ }^{14}$ Between 1566 and 1575, 31 million (current) ducats lent through asientos were collateralized with juros $-86 \%$ of the total volume lent. Over the same period, estimates of the increase in outstanding juros range between 11 and 17.5 million ducats. ${ }^{15}$

The first and second defaults, shortly after Philip II's accession to the throne in 1556, affected asientos contracted with the German Fugger and Welser banking families. Two rounds of negotiations brokered by Genoese bankers resulted in the settlement of 1560, which involved the transfer of Crown monopolies and revenues. ${ }^{16}$ The Genoese bankers also introduced a number of contractual innovations that we shall discuss shortly. The archival series of short-term borrowing, on which our analysis relies, starts in 1566, when the new system was already in full operation.

The third bankruptcy took place in 1575. It involved a suspension of interest payments, repayments of principal, and service of long-term bonds held by the bankers as collateral. It affected 12.3 million ducats of outstanding debt, or 1.9 times annual revenue. The bankruptcy occurred at a time of particular strain on Royal finances. Expenses to defuse the Ottoman threat in the Mediterranean continued to run high, and

\footnotetext{
${ }^{13}$ The superiority of the bankers in assessing the fiscal health of the Crown was widely acknowledged by Royal officials. Juan de Ovando, who was in charge of the initial stages of the 1575 restructuring, described the Royal treasury officials' "lack of order in books and papers, their bad diligence and low reliability." In the end, the king had to appoint Juan Fernández de Espinosa, a banker himself, to oversee the general settlement (Carlos Morales 2008, p. 151).

${ }^{14}$ Carlos Morales (2008, pp. 95-96).

${ }^{15}$ The estimate of 11 million ducats is from Artola (1982, pp. 88-89). The estimate of 17.5 million ducats was calculated by the king's treasurer, although it almost certainly included collateral juros not yet sold on the open market (Carlos Morales 2008, pp. 142-3).

${ }^{16}$ Lovett (1980); Alvarez Nogal (2003).
} 
the Dutch Revolt was flaring up in earnest. The king, meanwhile, used the default to negotiate a large tax increase with the Cortes.

The Genoese bankers formed a consortium representing about $70 \%$ of outstanding debt. Both sides engaged in bilateral negotiations, looking for exemptions from the payment stop and special deals, but no such bargains were struck. All lending, both by Genoese bankers and by those of other nationalities, stopped. The third bankruptcy concluded with a medio general, a general accord with the bankers, in 1577 . The agreement provided for write-offs of between $30 \%$ and $58 \%$, depending on the characteristics of each loan. On average, the king agreed to pay back $62 \%$ of his scheduled obligations. Repayment took the form of new long-term bonds, whose issuance was made possible by new taxes voted by the Cortes. In exchange for recognizing his earlier debts, Philip obtained a new loan for 4.2 million (current) ducats from the bankers on whom he had defaulted. ${ }^{17}$

The fourth bankruptcy, in 1596, involved a rescheduling of 5.4 million ducats, equivalent to $62 \%$ of annual revenue. Once again, the trigger for the suspension of payments was a combination of negative fiscal news and battlefield setbacks. In 1594 the silver fleets did not sail, and the remittances of 1595, though larger than usual, failed to make up for the shortfall. On the military front, the outbreak of the Elizabethan War necessitated high expenses to confront a potential invasion by British forces.

Compared to the third bankruptcy, the fourth was mild. The earlier one had involved asientos worth more than twice as much (at constant prices) and at a time when Royal income was significantly smaller. Philip's last default was also settled in swift order; by late 1597, a new medio general was in place and lending had resumed. The percentage subtracted from the principal amounted to $20 \%$ of outstanding debt, an amount worth less than one fourth of the 1577 write-off.

The king's defaults are best characterized as "excusable" in the sense of Grossman and Van Huyck (1988). They occurred when tax receipts and other forms of revenue were unusually low, and they were settled once the negative shocks had been reversed. In Figure 3, we plot total income relative to trend for the period as a whole.

\footnotetext{
${ }^{17}$ In keeping with medieval legal conventions, the king recognized the full face value of his debts. Our calculation of the haircuts takes into account the present value of the financial instruments offered as payment when compared to the original promises.
} 
Defaults are highlighted in grey. At the time of each default, revenues had been well below the trend for several years. Royal income surged after the payment stops of 1560 and 1575 , facilitating the negotiation of a settlement.

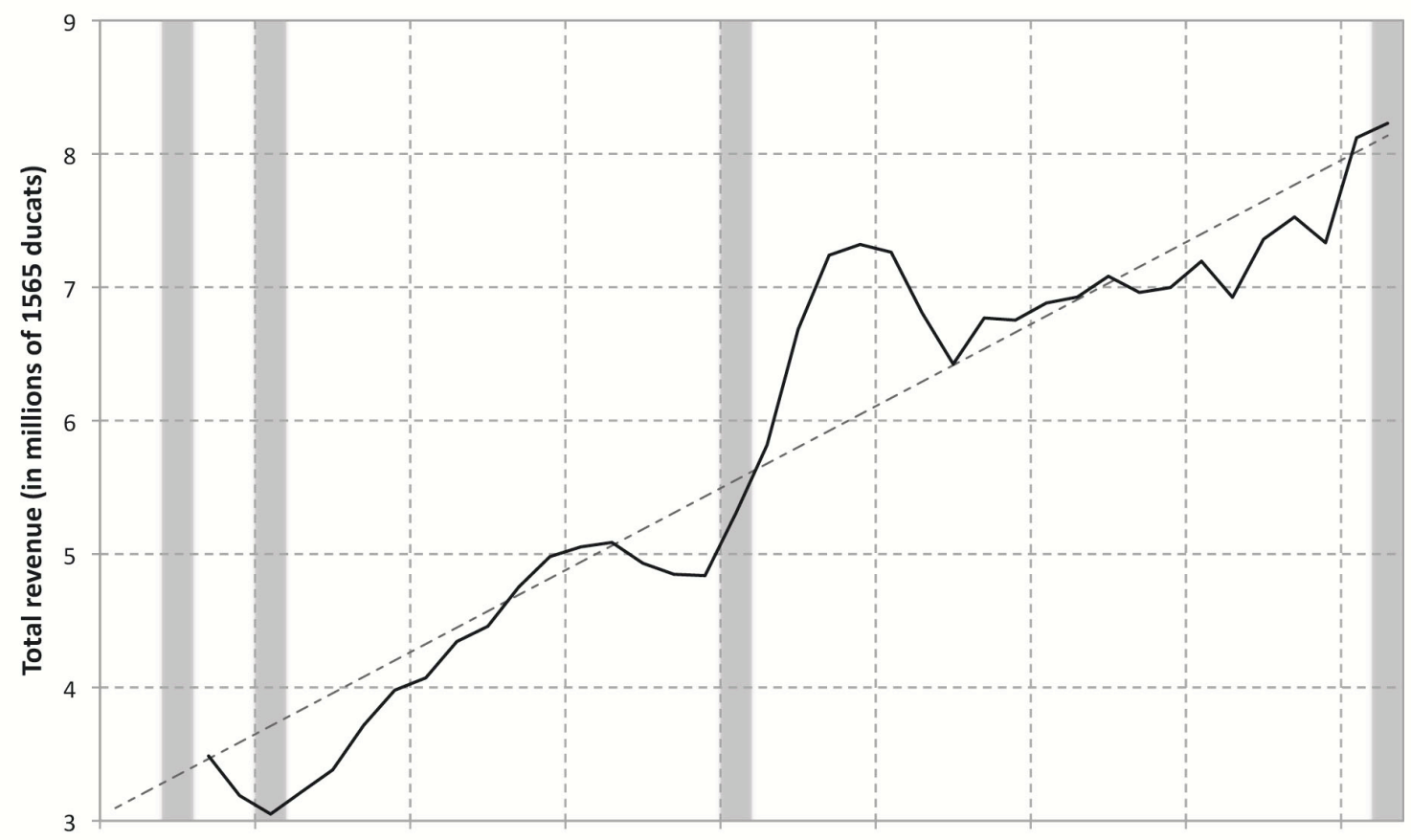

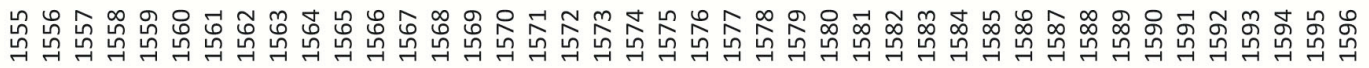

Year

Figure 3: Crown revenue for $1555-1596$, trend and five-year moving average (shaded years $=$ defaults)

The environment in which lending to the King of Spain occurred was "anarchic" (Kletzer and Wright 2000). The king could not credibly commit to repay his lenders. Contracts were frequently violated: more than $20 \%$ of the loan documents contain detailed references to earlier contracts that were not completely fulfilled. Although the king never rescheduled juros, payments could be less than promised — especially if the juros had been secured against a poor tax stream. ${ }^{18}$ Optimal Ramsey taxation suggests that the king should have defaulted on both asientos and juros if the cost of doing so was similar in both cases. ${ }^{19}$ There is no good estimate of the losses sustained by juro holders as a result of excess issuance relative to the size of a tax stream, but anecdotal evidence points to

\footnotetext{
${ }^{18}$ At various junctures, the king and his advisors considered forced conversions but ultimately decided against them (Braudel 1992).

${ }^{19}$ We thank Daron Acemoglu for this point.
} 
average trading discounts of about $7 \%$ toward the end of the 16 th century (Toboso Sánchez 1987). In some extreme cases, juros could trade at deeper discounts. ${ }^{20}$

Bankers could not commit effectively, either. In some cases, foreign bankers failed to return deposits made by the Spanish Crown, normally because of solvency problems. At each stage, Philip II and his bankers renegotiated the terms under which he could borrow. Between full compliance and outright repudiation was a wide range of possible outcomes. King and bankers engaged in the kind of constant recontracting we might expect in an environment without effective third-party enforcement (Bulow and Rogoff 1989a). In this sense, Philip's “defaults” were no different in principle from the renegotiation that occurred at every stage of interactions between borrower and lender; they were simply more substantial renegotiations.

As a consequence of the "anarchic" environment, the king had access to few smoothing mechanisms. Three should have been available to him: short-term borrowing, depositing funds with bankers, and long-term borrowing. Given the high frequency of the king's spending, only the first of these mechanisms was feasible. Foreign bankers could and did default on deposits the king had made with them. Enforcement across borders was slow and tortuous. ${ }^{21}$ In such an environment, depositing funds with a banker was not a viable alternative to the income smoothing that could be obtained from borrowing. ${ }^{22}$

The third alternative, the sale of juros to smooth out revenue variability and sustain spending, was feasible. However, it was too cumbersome to provide the king with quick access to funds. Especially in times of war, long-term bond issuance was not a viable alternative to short-term issuance. In addition, issuance of juros was limited by law to what could be serviced with regular, authorized tax revenues (e.g., they could not be serviced with silver revenue). Changing these limits required long, arduous, and often

\footnotetext{
${ }^{20}$ One example is the case of juros guaranteed by the taxes on silk in the area of Granada. A rebellion of the morisco population in 1568-1571 destroyed much of the stock of mulberry trees, which caused the silk industry to collapse. The juros supported by this revenue stream were soon trading at $40-50 \%$ below par. ${ }^{21}$ See, for example, Archivo General de Simancas, Contadurías Generales, Legajo 84. "Tomás de Marín. Asiento tomado con Pirro Boqui en su nombre." The document describes how a Genoese banker failed to return a deposit of 300,000 ducats that he held on behalf of the king. We learn of this because the issue is settled through the intervention of a third banker, who agrees to lend an equivalent sum at a preferential rate in exchange for the king dropping the proceedings against the banker who defaulted.

${ }^{22}$ In this sense, the alternative considered by Bulow and Rogoff (1989a) was not available to the King of Spain.
} 
unsuccessful negotiations with the Cortes. In combination, these factors mean that Philip could effectively smooth expenditures only through short-term loans.

\section{Data}

We collected a new, comprehensive set of short-term loan contracts (asientos) between Philip II and his bankers. ${ }^{23}$ The series, preserved in the Archive of Simancas, starts in 1566, ten years after Philip's accession. In order to capture the aftermath of the 1596 default, we use the complete set of contracts until 1600, two years after Philip's death. Earlier authors used data on lending volume, but these loan contracts contain a wealth of additional information that has never been exploited. This information includes details concerning the identity of lenders, the services performed, and the particular contractual arrangements. ${ }^{24}$ In Section IV we will focus on the detailed micro-data on lending contracts that were extracted from the archival records.

Financial transactions between the bankers and the king involved transfers, loans, or exchange operations - usually in combination. Transfers allowed funds to be disbursed in distant locations. For example, the king would often pay a banker cash, in advance, to have funds paid out in Flanders, in Italy, or in other areas. Exchange operations normally specify the currencies involved, the exchange rate to be used, and rules regarding permission to export specieout of Spain. The contracts are generally between 4 and 20 pages in length. In addition to the amounts lent and the repayment schedule, contractual clauses often stipulate the places of delivery and repayment, the fiscal streams from which the amounts were to be repaid, as well as transfer and exchange fees. In some cases, the king posts collateral in exchange for a loan. There is also a variety of other benefits and privileges that bankers receive in exchange for services rendered. These range from lifetime pensions to the award of noble titles. In numerous contracts, the time

\footnotetext{
${ }^{23}$ Archivo General de Simancas (henceforth AGS), Contadurías Generales, Legajos 86-93. Our series is missing nine contracts because of physical deterioration in the archival documents. The dates of the missing observations are evenly spread between 1578 and 1598 .

${ }^{24}$ The standard series in use is by Ulloa (1977). It suffers from the double counting of asientos contracted by field commanders in Flanders, which left most details to be negotiated later in consolidated contracts between the king and the bankers' representatives in Madrid (Lapeyre 1953, p.48). Our database includes only the final agreements, which superseded those made elsewhere and fully specified all terms and conditions.
} 
of repayment is contingent on the king's fiscal position (e.g., as a function of the silver fleet's annual arrival).

Heavy borrowing by the Habsburgs began as early as 1519, when Jakob Fugger the Rich financed Charles V's successful bid for the Holy Roman Crown. Charles's loans were small by the standards to be set by his son, Philip II. ${ }^{25}$ Regular borrowing in Philip's reign started after resolution of the second bankruptcy. After 1566, when our database starts, the king concluded an average of 12.5 asientos per year-sometimes none and in other years as many as 38 . Their duration varied between a few months and several years. In our sample, the greatest length between intended disbursement and repayment is 134 months. In contrast, several contracts are for transfers that were repaid within days of delivery. Excluding the loan negotiated as part of the general settlement of 1577, the largest contract was for 2.08 million ducats; it was concluded in 1589 and was equivalent to $30 \%$ of that year's fiscal revenue. The smallest contract was for a mere 1,663 ducats.

Table 1: Descriptive statistics

\begin{tabular}{lrrrrc}
\hline & Mean & S.D. & Min. & Max. & $N$ \\
\hline Principal & 190,080 & 275,853 & $1,663^{\mathrm{a}}$ & $2,386,755^{\mathrm{b}}$ & 438 \\
FX & 0.418 & 0.494 & 0 & 1 & 438 \\
Duration & 22.605 & 20.286 & 0 & 134 & 438 \\
Stated $r$ & 0.099 & 0.039 & 0 & 0.16 & 318 \\
Collateral & 0.320 & 0.467 & 0 & 1 & 438 \\
\hline
\end{tabular}

Note: Principal is given in constant 1565 ducats. FX is a dummy variable for the presence of a foreign exchange transaction. Duration is given in months, and $r$ is the nominal rate stated in the contract. Collateral is a dummy variable for the presence of collateral.

${ }^{a}$ The minimum value for principal is calculated excluding nine contracts that merely restructured old loans; because they did not result in fresh cash for the king, they are deemed to have a principal of zero.

${ }^{\mathrm{b}}$ The maximum loan corresponds to a portion of the general settlement of 1577 , which was apportioned between four banking syndicates. The largest contract excluding the settlement was for 2.08 million ducats.

Foreign exchange transactions (almost always involving the transfer of funds abroad) appeared in $42 \%$ of all contracts. The interest rate stated in the loan document averaged $9.9 \%$. It could be as low as $0 \%$ (usually in special cases, as when the funds were used for the construction of ecclesiastical buildings) and as high as $16 \%$. In many cases,

\footnotetext{
${ }^{25}$ The standard source on Charles V's borrowing is Carande (1987).
} 
the king would offer collateral as well, pledging juros that could be sold to other investors in case he failed to pay on time and in full.

Philip borrowed from several banking families. No fewer than nine members of the Lomelín family entered into loan contracts with the Spanish sovereign. The Spinola family contributed twelve lenders, the Gentil ten, the Centurión six, and the Fugger five. ${ }^{26}$ Several members of the same banking family often lent through a single contract. For example, on 13 March 1572 we find Gerónimo and Esteban Grillo lending 100,000 ecús to the king and making them available in Sicily. ${ }^{27}$ The brothers Augustín, Tadeo, and Pablo Gentil entered into several joint contracts between 1567 and $1569 .{ }^{28}$ Lending in small-scale syndicates was common in our data set. Of 438 total transactions, 141 had multiple lenders and accounted for $30 \%$ of total lending volume.

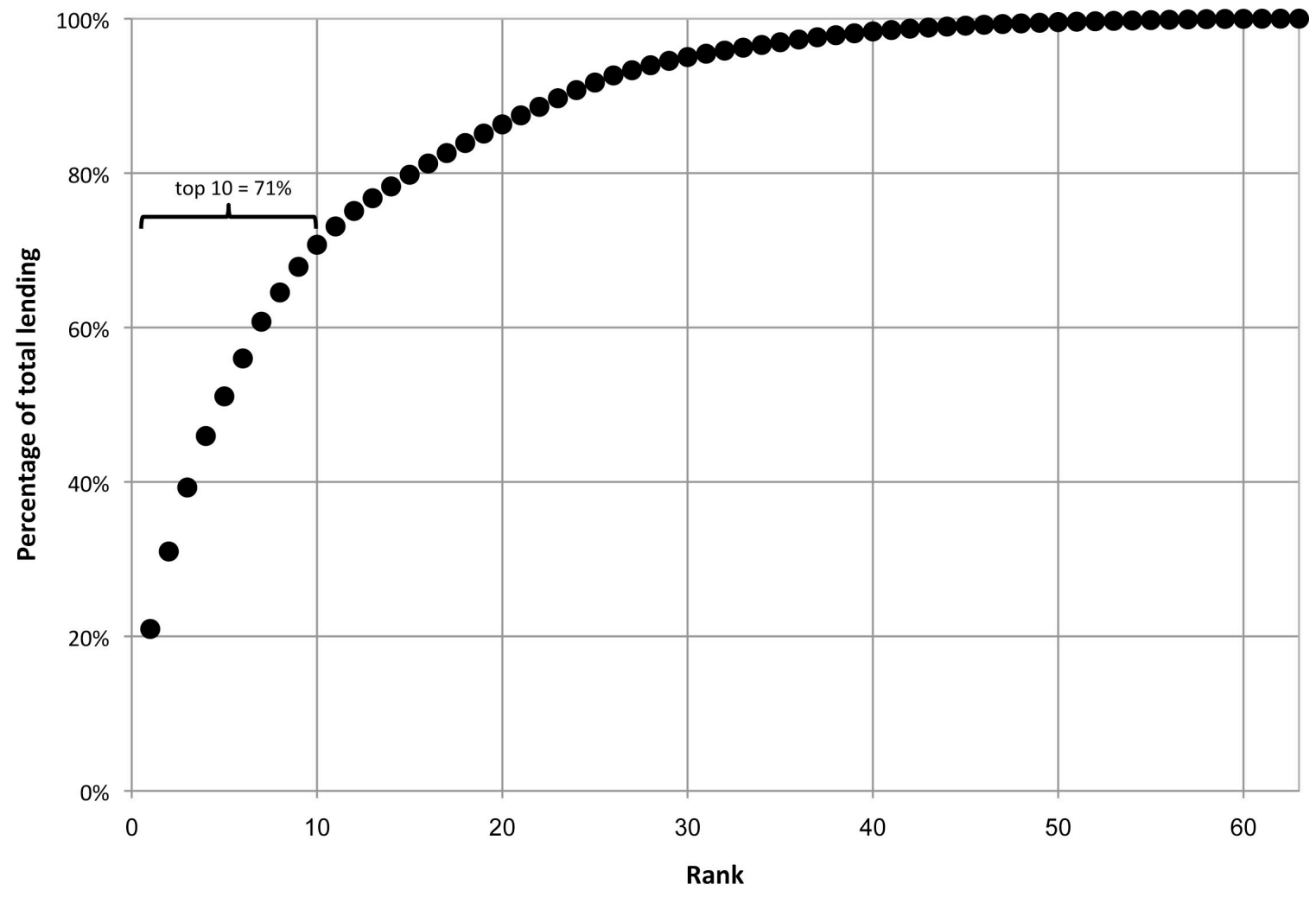

Figure 4: Cumulative lending to Philip II by rank of lending family, 1566-1600

\footnotetext{
${ }^{26}$ We use the Spanish spelling of the banking families' names throughout, as they appear in the archival documents.

${ }^{27}$ AGS, Contadurías Generales, Legajo 85. "Gerónimo Grillo y Esteban Grillo. Traslado del asiento con ellos tomado a 13 de marzo de 1572."

${ }^{28}$ AGS, Contadurías Generales, Legajos 84 and 85.
} 
Lending was heavily concentrated. Although 130 individuals from 63 families lent to Philip II at some point, a handful of them provided the bulk of resources. The Spinola, Grimaldo, and Fugger families alone accounted for almost $40 \%$ of the value of loan contracts. The top 10 banking families were responsible for more than $70 \%$ of all loans; the top 20 banking families, for $86 \%$. The bottom 48 lenders combined provided less credit than members of the Spinola family, the biggest bankers to Philip II. Figure 4 plots the cumulative percentage of the total amount lent to the Crown against the rank of the banking family. The distribution is highly unequal (Gini coefficient of 0.73 ).

These lending relationships were significant not only in terms of total volume provided. They also proved to be enduring, with lending continued by one generation after another. The Fuggers started lending to Charles V early in the century and continued all the way to 1596 without ever stopping for more than nine consecutive years. Jakob Fugger lent to Charles V in 1519; his nephew, Anton Fugger, lent again in the 1550s; and in 1590 we find his great-grandson, Marcos Fugger, doing the same. The Grimaldo family lent 27 times between 1566 and 1589. The record holders in terms of frequency were the Spinola, whose members participated in a total of 98 loan contracts over the period 1566-1599.

One useful feature of short-term asientos was that they could be used for transferring funds to far-flung corners of the empire. This, however, was not a dominant characteristic of contracts before 1575. Table 2 summarizes the place for delivery of funds by bankers before and after the 1575 default. Fully $62 \%$ of the amount borrowed was delivered outside Castile. Flanders was the most important foreign destination for funds because of the costly war there against the Dutch rebels. Italy was a distant second, partly because the king was able to rely on local revenues to fund his Mediterranean fleets. $^{29}$

\footnotetext{
${ }^{29}$ Parker (1998, p. 135).
} 
Table 2: Place of delivery of asientos

\begin{tabular}{lcr}
\hline \multicolumn{3}{c}{ Delivery } \\
Location & In 1566 ducats & In percent \\
\hline Castile & $31,407,408$ & $37.8 \%$ \\
Flanders & $30,383,774$ & $36.5 \%$ \\
Italy & $16,588,412$ & $19.9 \%$ \\
Elsewhere & $4,808,984$ & $5.8 \%$ \\
& & \\
Total & $83,188,578$ & $100 \%$ \\
\hline
\end{tabular}

Although the borrowed funds were made available in different locations throughout the empire, repayment took place for the most part in Castile. We find that $95 \%$ of loan repayments were made from Castilian sources, either domestic tax streams or silver remittances from the Indies. This is consistent with the idea that the Spanish Empire, for all its extension and might, was primarily financed by a Castilian economy that was among the strongest in Europe at the dawn of the early modern age (Alvarez Nogal and Prados de la Escosura 2007).

\section{Analysis}

In this section we discuss what sustained the sovereign borrowing of Philip II. We first analyze who lent. If groups of overly optimistic bankers were disappointed sequentially, then default episodes should be followed by massive turnover in the group of lenders: new entrants should have replaced existing bankers, but we show that turnover was minimal. Next, we turn to the "transfer stop" hypothesis presented by Conklin (1998) and demonstrate that a cessation of transfers never occurred - it is a punishment that wasn't. Though the Genoese did not transfer funds for the Castilian crown, they failed to effectively punish the king in this way. Instead, other financiers stepped in and offered sufficient transfer services.

Our interpretation emphasizes coordination among bankers and the incentive structure driven by the king's borrowing needs. We demonstrate that the Genoese lenders were intimately connected, through the contractual form of lending, and formed a bankers' coalition. When this coalition imposed a borrowing stop on the king, no outsiders lent, either. This is because the king would have defaulted on any banker who broke the moratorium, as in the setup described by Kletzer and Wright (2000). 
Contemporary correspondence shows that bankers were gravely concerned about this possibility and hence did not break the moratorium.

\section{Banker Turnover}

Braudel (1966) argued that Philip II managed to borrow massively, default often, and pay back little because he repeatedly fooled his bankers. First it was the turn of German financiers to be ruined, who lent based on the reputation of Philip's father, Emperor Charles V (with whom they shared a personal relationship). Then came the Genoese, who bankrolled Philip's early years. After the 1575 default, Braudel argued, new money was provided by Spaniards. When these bankers were ruined by Philip's fourth and last default in 1596, he could only turn to the Portuguese.

The traditional story of sequential default and financial ruin requires a fair deal of banker irrationality. Modern-day journalistic references to Philip's defaults often make this point, referring to bank lending as "a sober business punctuated by odd moments of lunacy. Genoese lenders' indulgence of Philip II of Spain's expensive taste for warfare caused not only the first sovereign bankruptcy in 1557, but the second, third and fourth as well." 30

As a first step, we examine the idea that successive waves of lemming-like lenders - first from Germany, then from Genoa, and finally from Portugal and Spainentered the borrowing game. We determine the nationality of the bankers in the complete set of 438 loan transactions in our database. The Genoese provided $66.9 \%$ of the loans before the 1575 bankruptcy and $63.5 \%$ after it. Contrary to the argument made by Braudel, the data show that the composition of financiers was remarkably stable during the second half of the 16th century. Spaniards did not enter in the last period, contrary to earlier claims in the literature. They were lending for most of the second half of the 16th century, and after 1575 their share actually declined from $28.8 \%$ to $25.6 \%$. The German bankers, who were allegedly burned by the first bankruptcy, also proved to be a continuous source of funding. In fact, their share more than doubled-from $4.3 \%$ to $10.9 \%$ - after the bankruptcy of 1575 . Thus there is little evidence to support Braudel's interpretation of lending as a repeated fooling of bankers from different countries.

\footnotetext{
${ }^{30}$ The Economist, 23-29 September 2006.
} 
Next, we examine how much lending after the third bankruptcy came from bankers who had lent before. Figure 5 shows the composition of lending before and after the default of 1575 . In the immediate aftermath of the settlement, all lending came from bankers who had made loans to the Spanish king beforehand. In the six years after 1576, $96 \%$ of funds were made available by lenders who had lent before the bankruptcy. As late as 1586, almost 9 out of 10 ducats borrowed by the king came from the same bankers who had financed his previous ventures. As time went by, the same banking families continued to provide a high (albeit eventually declining) share of total funding. In 1596, more than $60 \%$ of funds borrowed in the short-term loan market still came from the same families that had been active before 1576 .

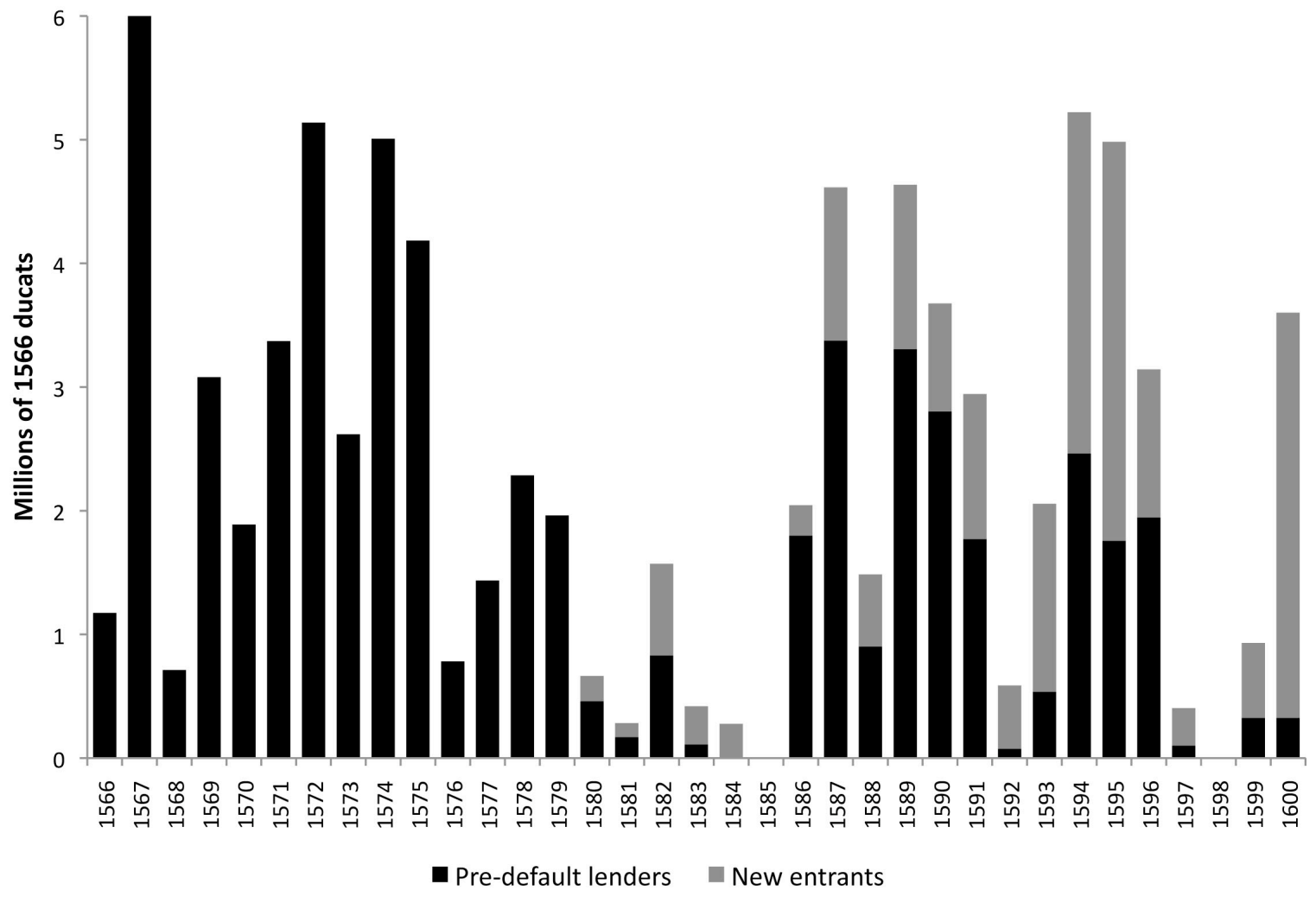

Figure 5: Value of lending by new entrants and by bankers with a pre-default relationship, $1566-1600$

Not all of the funds provided after the bankruptcy came from earlier creditors. A key question is: Was the frequency of repeat business unusually low after the bankruptcy? Defining repeat lenders as those who offered funds during one of the preceding 50 transactions, we obtain a time-varying measure of banker turnover. There are 438 transactions in our sample, so this approach is equivalent to examining a moving window 
that contains a little more than the previous $10 \%$ of loans. The volume of lending by bankers without a prior relationship was small throughout (see Table A1 in the Appendix). During the period as a whole, an average of $85.4 \%$ of borrowing came from bankers who had lent during one of the last 50 loan transactions. In the seven years before the 1575 suspension, $91 \%$ of lending was repeat business; for the seven years following the suspension, this figure was $89 \%$.

Repeat lending continued across the time of bankruptcy, and much of Philip's borrowed money came from bankers who had lent to him before 1575. Bankers with earlier connections made large contributions to total volume. It is nonetheless possible that other financiers, whose expectations were disappointed by the bankruptcy and its resolution, decided to cease such lending activities. To examine this possibility, we reverse our earlier procedure and look at exits from the pool of active bankers. Toward this end we classify loans based on whether the banker will (ever) lend after the current contract. Figure 6 shows the results.

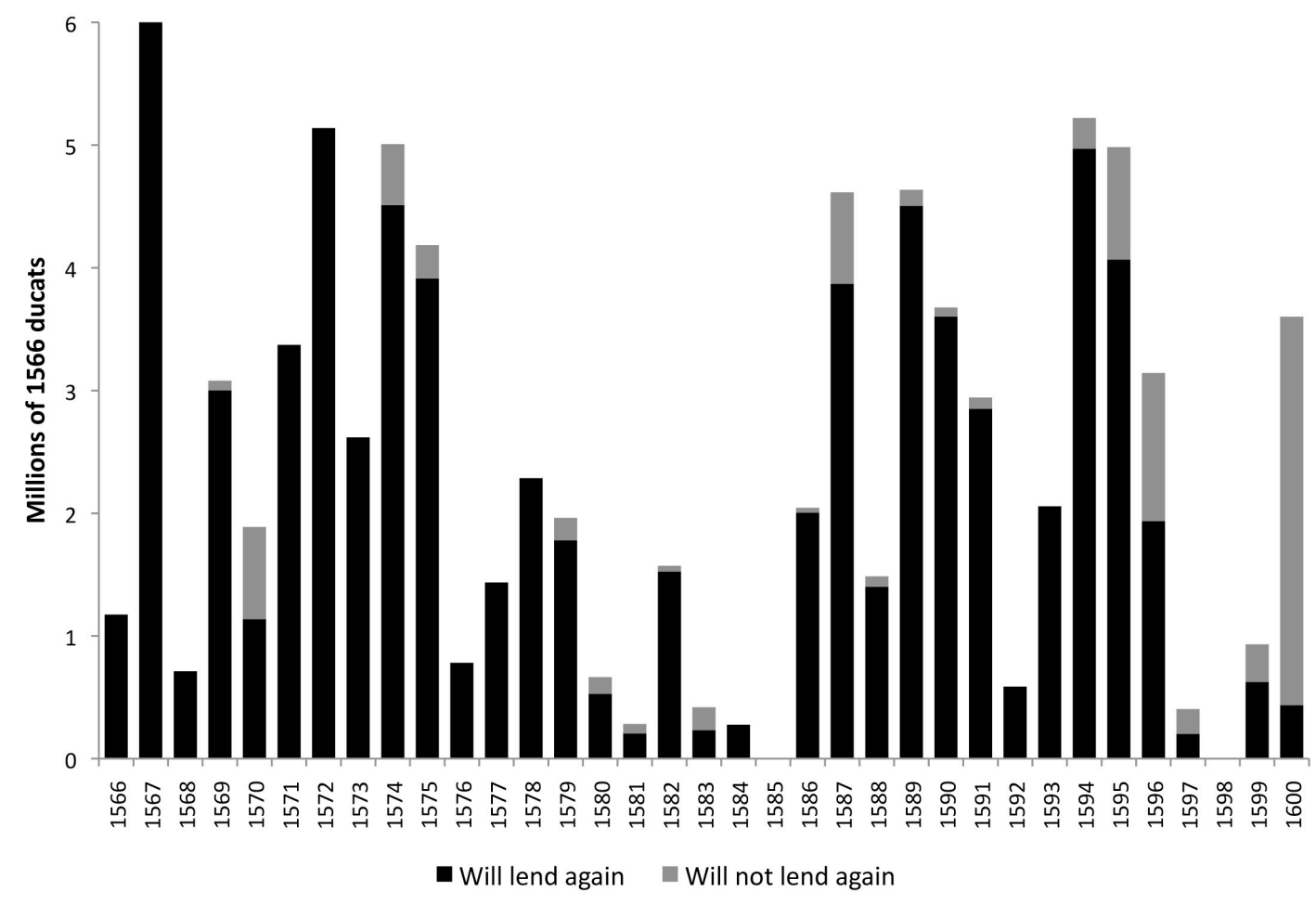

Figure 6: Annual volume lent in terms of future interactions with the king 
Few lenders terminated their lending relationship with Philip II. Conditional on having lent in a single transaction, the chance that the same banker will enter into another contract is $88 \%$. Crucially, the period before the bankruptcy of 1575 does not show a spike in bankers who subsequently exit our sample. Bankers who lent before the bankruptcy had a 3.8\% likelihood of dropping out of the business versus $4.4 \%$ afterward. Because our data set ends in 1600, those lending for the first time later in our sample period have less of a chance to enter into repeat business. This explains the gradual increase of the proportion in the "never again" category over the final few years.

The 1575 bankruptcy was the biggest default in Philip II's reign. Nonetheless, lenders who had established a business relationship with Philip before 1575 were not likely to terminate it afterwards. Repeated lending by the same banking family constituted a steady proportion of total funding. Turnover among the group of lenders maintaining a lending relationship was constant throughout our sample. Few bankers exited the business, and their proportion did not rise after the events of 1575 . These results suggest that, by and large, the same financiers lent to Philip before and after the 1575 bankruptcy. The folly of bankers - lured into lending by the king, only to be ruined by repeated defaults - cannot account for the behavior we document.

After the 1577 medio general, there was little lending. Is there reason to think that access to credit suffered after the default? We argue that this is unlikely, for two reasons. First, Philip received a fresh loan (worth 4.2 million ducats over three years) provided by the most influential lenders prior to the default: the Grimaldo, Lomelín, de la Torre, Centurión, Spinola, Grillo, Cattaneo, Lercaro, and Gentil families. This is comparable to the peak volume of pre-default lending. Second, both ordinary tax revenues and silver remittances were unusually strong in the years 1576-1581. Figure 3 (in Section II) shows the evolution of total revenues relative to trend. The fiscal and military crises allowed the king to negotiate a large tax increase with the Cortes. Part of the increase was frontloaded, leading to a temporary spike in tax collection. Sales-tax revenue grew from 1.1 million ducats in 1575 to 3.2 million in 1576 and 1577 before settling down to an annual rate of 2.4 million, more than twice its pre-default level. ${ }^{31}$ This income was reinforced by

\footnotetext{
${ }^{31}$ All the fiscal data are from Drelichman and Voth (2007).
} 
a windfall of silver revenue. In 1577, the king's $20 \%$ of silver imports amounted to almost 2 million ducats; the average during 1570-1575 had been only 0.7 million.

Overall, lending declined by 2.1 million ducats per year for the eight-year period following 1576 when compared with the preceding eight years. Over the same time frame, revenue was up by 1.8 million ducats. In addition, the intensity of warfare in the Low Countries declined following the Pacification of Ghent. It is therefore unlikely that the Crown was shut out of credit markets after the medio general. Thus the observed decline in borrowing was in all likelihood the result of unusually strong tax revenues driven by windfalls from silver and the rise in taxes negotiated with the Cortes.

The results presented in this section suggest that banker irrationality is not a probable explanation for continued lending to Philip II. The same banking families, from the same countries, supplied funds to the monarch. They did so regardless of the defaults: the rate of banker turnover does not change after the payment stops were instituted. This makes it unlikely that moderate levels of lender sentiment, as suggested by Braudel, were responsible for the king's continued access to funds. However, we cannot entirely rule out extreme forms of banker irrationality - that is, financiers continuing to engage in a business with negative profitability.

\section{Stopping Transfers}

Conklin (1998) concluded that sanctions sustained lending to Philip II, which is in line with the arguments of Bulow and Rogoff (1989a). In this view, the Genoese punished the Spanish king by refusing to transfer funds to his armies in the Netherlands. Military disaster ensued, the king settled with his bankers, and the penalty was revoked. Yet the tale has one crucial shortcoming: the penalty was never effective.

Success against the Dutch rebels was critical for Philip II's "grand strategy" (Parker 1998). Under the Duke of Alba, Spanish forces during the years 1570-1573 mounted a major offensive to subdue the rebels. ${ }^{32}$ Expenditures for the war ran close to 2 million ducats per year at a time when total annual revenue was no more than 5 million. According to Conklin, Philip had few (if any) options for transferring funds to Flanders

\footnotetext{
${ }^{32}$ Parker (1998, pp. 143-4) argues that in 1572 the Spaniards came "within a hair's breadth" of ending the revolt. Failure to subdue the rebels was, in his view, was caused by political mistakes rather than by lack of funds.
} 
besides resorting to the Genoese. Physically shipping silver was too dangerous, and sending coins through hostile France was impossible. Transfer by boat via the English Channel could be hazardous, as evidenced by earlier gold transfers that had been seized by privateers, ${ }^{33}$ and the Spanish road from Italy to the Netherlands was considered too dangerous and expensive.

Because transfer operations are separate from credit operations, the Genoese could have continued to transfer funds even though their loans were in default. By refusing to do so, according to Conklin, they imposed a severe penalty: "It is abundantly clear, however, that freezes on lending and on transfers were forcefully imposed from 1575 to $1578 \ldots$ with the consequence that the Crown's capacity to make war beyond its borders was seriously impaired until it reached an agreement with its lenders" (Conklin 1998, p. 492). The crucial problem with the penalty argument is that transfers actually continued at a healthy pace during the suspension of payments. There is no evidence that the Genoese "transfer embargo" had any effect on the availability of funds in the Flanders theatre of war. Table 3 shows a time series of transfers to Flanders between 1566 and $1577 .^{34}$

\footnotetext{
${ }^{33}$ Lovett (1982, p. 15).

${ }^{34}$ Our coding of the asientos in the archive of Simancas allows us to separate transfers to Flanders from those to other destinations, which were not part of the penalty suggested by Conklin. The transfers during the bankruptcy years are also discussed in Lapeyre (1953, p. 22), Vázquez de Prada (1960, pp. 330-3), and Ulloa (1977, pp. 795-6).
} 
Table 3: Amounts transferred to Flanders (ducats)

\begin{tabular}{rr}
\hline Year & \multicolumn{1}{c}{ Transfers } \\
\hline 1566 & 390,111 \\
1567 & $1,830,243$ \\
1568 & 92,040 \\
1569 & 180,394 \\
1570 & 130,384 \\
1571 & 0 \\
1572 & 434,248 \\
1573 & 925,937 \\
1574 & $1,479,735$ \\
1575 & $1,610,422$ \\
1576 & $889,988^{\mathrm{a}}$ \\
1577 & $1,192,933$ \\
\hline
\end{tabular}

Note: The 1577 value is the amount transferred before the medio general.

${ }^{\mathrm{a}}$ In addition to this amount, Conklin (1998, note 11) reports that the Crown physically transported slightly under 400,000 ducats to Flanders in 1576.

Sources: Archivo General de Simancas, Contadurías Generales, Legajos 86-93; Vázquez de Prada (1960, pp. 330-3).

The decree suspending payments was issued on 1 September 1575 . Following this, the Genoese stopped all lending and transfers. However, after the sack of Antwerp in November 1576, most Genoese families fled Flanders. They did not return until 1582, when the Spanish gained control once more. Hence they could hardly have used the resumption of transfers as a bargaining chip (Goris 1925, pp. 394-8).

Other bankers did not lend, but they did transfer funds if they received silver up front. In total, German and Spanish bankers transferred 2.08 million ducats on behalf of Philip II during the two years of the suspension. Fully half of this amount was transferred by the Fugger family and its correspondents, with the remainder entrusted to an emerging group of Spanish merchants. ${ }^{35}$ If one adds the 400,000 ducats that the Crown itself transported to Flanders, the result is an average of 1.24 million ducats per year. In the three years previous, remittances ran at 1.34 million per annum; if the four previous years are considered, the yearly average was 1.11 million. Viewed from this perspective, the suspension of payments had virtually no effect on the Crown's ability to transfer funds to

\footnotetext{
${ }^{35}$ Ulloa (1977, pp. 795-6).
} 
its troops. Transfers in 1576-1577 were low only when compared to the peak remittances of 1574 and 1575, and even then they were at two thirds of the peak level.

To the extent that remittances were somewhat lower in 1576-1577, the inability to transfer was not to blame. In the two years before the bankruptcy, the king had received loans and silver revenue to the tune of 13 million ducats; in the two years after, he had access to only 3.3 million. Ordinary revenues rose by approximately 2.5 million ducats. Free cash flow was therefore down by more than half, a fall more than sufficient to explain the decline in transfers. The correspondence of government officials demonstrates that a shortage of available funds, and not a lack of transfer facilities, was the principal constraint. In September 1576, a Royal official by the name of Gaztelu writes to one Juan de Zuñiga: "Experience shows each day that it is impossible to continue without loans and we risk losing everything. With the money that has been sent abroad there is none left to be found in Spain." ${ }^{36}$ While noting the risks and costs of shipping funds, Gaztelu gets at the heart of the matter: there were no funds left to transfer. As the liquidity crunch eased, spending and transfers revived. In 1577, when silver revenue reached a record 2.2 million ducats, payments to Flanders increased rapidly even before the medio general settled old claims by the creditors. While lending stopped altogether, transfer services were readily available at little or no extra cost as long as the king was willing to supply ready cash. Hence the Genoese transfer embargo had no bite. In short, we must turn elsewhere in order to explain why lending to Philip II was sustainable.

Philip exempted one banking family from the bankruptcy decree-the Fuggers. They were essential for the continued transfers after 1575. With regard to the Fuggers, the Conklin argument is correct: the threat of transfer services being withdrawn was enough to prevent the king from stopping payments. After the departure of the Genoese from the Low Countries in 1576, only the German family maintained a substantial network of correspondents there. Yet not even the Fuggers continued lending after 1575, despite being exempt from the payment stop. The king's transfer needs could be met by a

\footnotetext{
36 “La experiencia va mostrando cada día que no se puede ir adelante sin cambios so pena que se perderá todo, porque con el dinero que se ha sacado ya no se halla niguno en España y es mucha la costa y grande el peligro y mayor la dilación que hay en llevarlo de contado a Flandes y a Italia." Quoted in Carlos Morales (2008, p. 174).
} 
single banking family, but his borrowing needs could not. We next describe how this simple fact helped sustain lending to an absolutist monarch such as Philip II. ${ }^{37}$

\section{The Genoese Coalition}

In this section we explore the nature of lending relationships within the single most powerful group of bankers to Philip II: the Genoese. They provided funds through syndicated lending in overlapping groups. This created a de facto network or alliance of financiers that would act as one, effectively forming a lenders' coalition. Contemporaries referred to them as such — that is, as a closely knit group of lenders from Genoa, subject to the same treatment by the king, and acting largely in concert. ${ }^{38}$ Much lending took place in simple bilateral contracts between the king and an individual banker. In numerous cases, however, lenders joined forces to provide funds. Approximately one third of all transactions involved more than a single banker. To take the dynastic nature of lending relationships into account, we focus on contracts that involved more than a single banking family. Some of these had ties through intermarriage, like the Grimaldo and Lomelín families, while others were connected only through business partnerships. ${ }^{39}$ To err on the side of caution, we count two banking families as being connected only if we observe them lending jointly to the king. ${ }^{40}$

Some of the co-lending relationships involved multiple loans by a stable group of bankers. For example, Lucián Centurión and Agustín Spinola together lent no fewer than seven times during 1566-1567. In other cases, the co-lending occurred only once. By tracing the connections between families through joint lending, we can examine the direct and indirect links that financiers established. Most of the network members were engaged in repeated interactions with each other. The Grimaldo and Spinola families often co-lent, as did the Judice and Doria and the Centurión and De Negro. One family stands out as the

\footnotetext{
${ }^{37}$ Whether the label "absolutist" is appropriate can be debated. In the comparative work of Acemoglu, Johnson, and Robinson (2005), Philip II is coded as a perfecty unconstrained ruler.

${ }^{38} \mathrm{Cf}$. the Fugger correspondence summarized in Karnehm (2003).

${ }^{39}$ For example, the text of the medio general specifies that Esteban Lomelín is Nicolao de Grimaldo's sonin-law. AGS, Consejo y Juntas de Hacienda, Libro 42. Similar family relationships are occasionally mentioned in the text of the asientos.

${ }^{40}$ Whether the Genoese with their high degree of collaboration constituted a cartel has been debated in the historical literature (Alvarez Nogal 2003). We do not take a view on their pricing behavior. We refer to them as a network simply because of their co-lending and their behavior during the defaults.
} 
"spider in the web": the Spinola. One of their transactions involved 16 other banking families as partners. In the language of network analysis, the "centrality" of the Spinola is very high. The next most central family, the Doria, lent together with seven other dynasties. The Doria and the Spinola networks were linked through loans the two families provided together as well as by both families co-lending with the Grimaldo, the

Lercaro, the Marín, and the Maluenda. All in all, the list of names on the asiento contracts with the Spanish crown reads like a "Who's Who" in Genoa, as the Spinola and Doria had played a leading role in Genoese politics since the 1270 s. $^{41}$

Figure 7 provides an overview of the network's structure. ${ }^{42}$

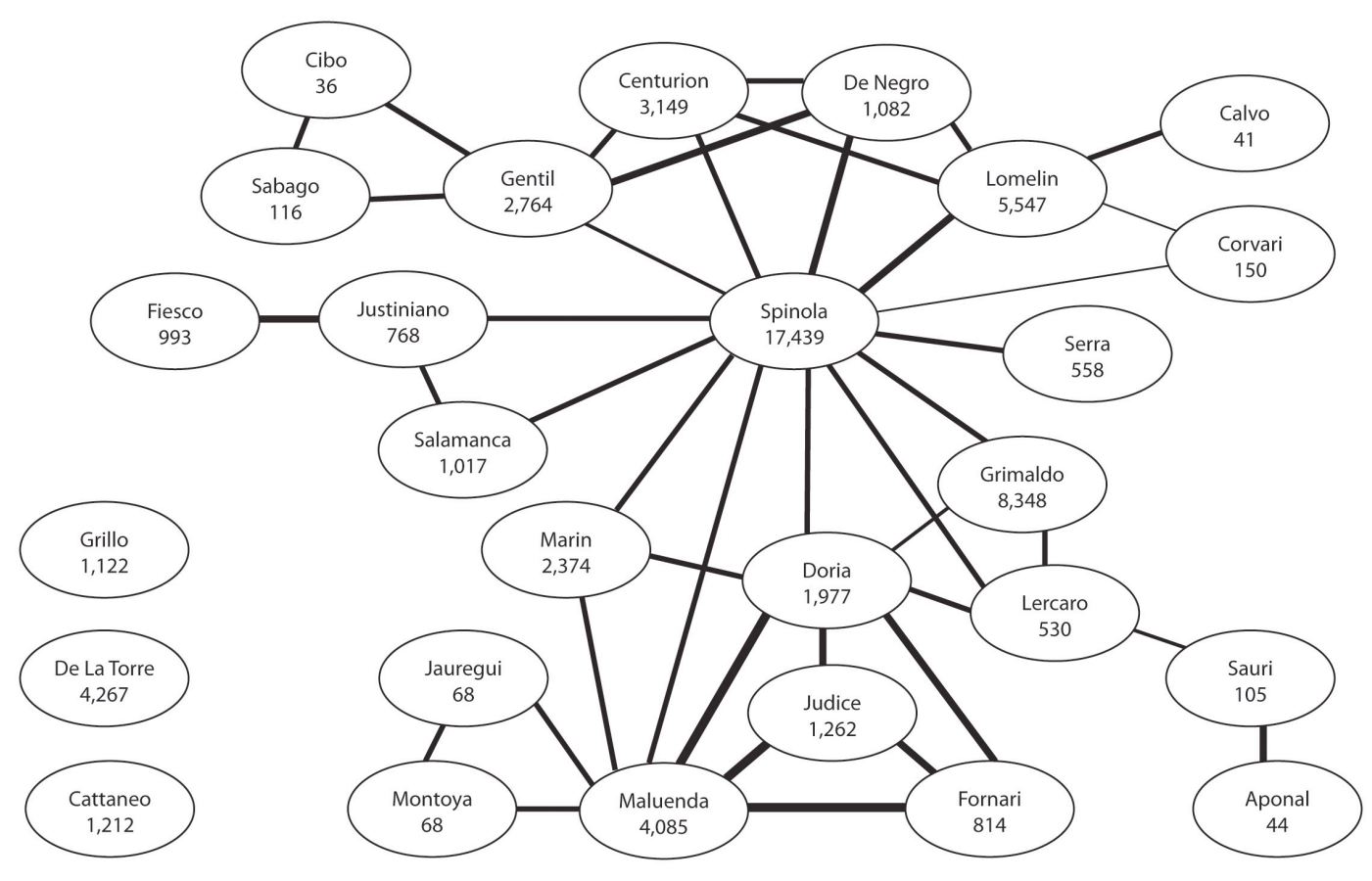

Figure 7: The Genoese network

\footnotetext{
${ }^{41}$ Andrea Doria became a famous admiral in the service of Charles V, and he helped reinstitute an aristocratic constitution in the first half of the 16th century. Battista Spinola served as Doge (chief magistrate) in the $1530 \mathrm{~s}$.

${ }^{42}$ The numbers below family names indicate total lending in thousands of 1566 ducats. The thickness of connecting lines indicates the average size of joint loans on a log scale. The Grimaldo, Lomelín, De La Torre, Centurión, Spinola, Grillo, Cattaneo, Lercaro and Gentil families are all linked in the four contracts stipulated in the medio general, but for clarity of exposition those links are not shown here (hence the three unconnected families on the left-hand side). The links established in those contracts are the strongest in terms of capital involved. In the Appendix, Figure A1 depicts the structure of the network when only the transactions prior to 1575 are taken into account, illustrating the links between bankers that participated in the medio general.
} 
Co-lending was not the only way in which the network operated. In many cases, collateral posted by the king was passed from one banker to the next without ever returning to the Royal treasury. This practice arguably made it much more difficult for the king to selectively default on an individual member of the Genoese coalition, ${ }^{43}$ since cross-posted collateral could easily have been seized by lenders left out of any deal. Collection of outstanding debts on behalf of other bankers was also common. In several asientos, the king borrowed from one banker and agreed to repay the loan in part or in full to a different person. The opposite also happens: the king promises repayment through other bankers. These agency relationships would have hindered side deals, particularly if bankers had open positions with each other.

For example, on 25 January 1567, Julián Spinola agrees to deliver 36,800 ecús (at various Italian ports) to be used in resupplying the king's galleys. ${ }^{44}$ The king promises to repay Bautista Spinola in Madrid at a later date. As collateral, Philip's Genoese ambassador deposits 20,000 ecús in Baltasar Lomelín's bank in Genoa. The contract specifies that, should the king fail to honor his obligations, Julián Spinola is entitled to receive the money deposited with Lomelín. In another case, the king borrows 80,000 ducats from Lucian Centurion and Agustin Spinola in $1569 .{ }^{45}$ Half of the repayment comes in the form of tax revenue; the other half is channeled through a group of six Genoese bankers. ${ }^{46}$ This type of arrangement would have made it extremely difficult for the king to default and then enter into a special deal with the Spinola family. They were substantial backers of Philip, lending the largest quantity (17 million ducats) of all banking families. Yet in these two contracts alone, had the Spinola cut the other bankers out of any arrangement, the equivalent of half the loan principal could have been seized.

\footnotetext{
${ }^{43}$ See e.g. AGS (Contadurías Generales, Legajo 85), where several loans made by Lorenzo Spinola are collateralized with bonds held by Nicolao de Grimaldo.

${ }^{44}$ AGS, Contadurías Generales, Legajo 84. "Julián Spinola. Asiento que el embajador Gómez Suárez de Figueroa avino en Génova con Julián Spinola."

${ }^{45}$ AGS, Contadurías Generales, Legajo 85. "Lucián Centurión y Agustín Spinola. Traslado del asiento con ellos tomado a 2 de mayo de 1569."

${ }^{46}$ These were Nicolás and Visconte Catano, Alberto Pinelo, Miguel de Mena, Constantin Gentil, Benito Sabago, and Juan Antonio de Negro. Many of them also lend in syndicated loans with the Spinola and Centurion families.
} 
Such losses would have made it quite costly for the Spinola to capture the surplus generated by the king's great need for funds after a bankruptcy.

Nor were all arrangements of this type meant to keep the powerful Spinola in check. In 1569, Philip borrows 213,000 ducats from Agustín, Pablo, and Tadeo Gentil. The contract provides for repayment through Lorenzo Spinola, who owed this amount to the king. In this case, had the Spinola been excluded from a special deal between the Gentile and the king, the Gentile would have sustained major losses. Similarly, on 5 March 1595 the king agrees to borrow 330,000 ducats from Francisco and Pedro de Maluenda. Repayment is via Adán de Vivaldo, from whom the king also borrows. Vivaldo, a Spanish banker, does not co-lend with the Genoese in any of our contracts. This reinforces the nature of our definition of the "network" as a lower bound on the true extent of multilateral relationships among bankers. Some of these relationships that emerge from our sources link members of the network that do not co-lend. The Lomelín and Grimaldo families do not join the same syndicates. Nonetheless, as part of a lending contract between the king and Baltasar Lomelín, in 1588 both Esteban Lomelín and Doña Sasandra de Grimaldo are allowed to change the tax stream against which their longdated debt is secured (a transaction that increases the value of the debt they hold).

Cooperation among bankers extended beyond the act of lending itself. In 1567, for example, Tomás de Marín accepted a deposit of 300,000 ducats from the king in Milan but then failed to produce the funds upon request. The king petitioned a court to declare Marín bankrupt. Early in the proceedings, however, Nicolao de Grimaldo stepped in, agreeing to provide a 300,000-ducat loan to the king in exchange for dropping the lawsuit against Marín. The deposit at Marín's bank was converted to a perpetual rent in favor of the king at $8 \%$ interest. ${ }^{47}$ As another example, in 1587 the king entered into an asiento for a million ducats with Agustín Spinola. As part of the conditions of the loan, the king agreed to drop a number of lawsuits against three other bankers, Lucián Centurión, Antonio Alvarez de Alcócer, and Manuel Caldera. ${ }^{48}$ Bankers also used their network clout to force the king to honor his commitments. For example, a 30,000-ducat

\footnotetext{
${ }^{47}$ AGS, Contadurías Generales, Legajo 84. "Tomás de Marín. Asiento tomado con Pirro Boqui en su nombre." We never observe Grimaldo and Marín lending together to the king. Nonetheless, they both belonged to the network because they did extend loans jointly with other bankers.

${ }^{48}$ AGS, Contadurías Generales, Legajo 88. "Agustín Spinola, hijo de Francisco difunto. Asiento tomado con él sobre un millón de ducados que provee en Italia."
} 
loan by Francisco Spinola in 1588 included a clause that required the king to settle an old debt with Lorenzo Lomelín. ${ }^{49}$

Table 4: Network lending (millions of 1566 ducats)

\begin{tabular}{lrcc}
\hline & \multicolumn{2}{c}{ Number of } & \\
& Families & Transactions & Volume lent \\
\hline Network & 27 & 308 & 59.9 \\
Nonnetwork & 36 & 130 & 23.2 \\
Total & 63 & 438 & 83.1 \\
& & & \\
Network & $43 \%$ & $70 \%$ & $72 \%$ \\
Nonnetwork & $57 \%$ & $30 \%$ & $28 \%$ \\
\hline
\end{tabular}

Source: Archivo General de Simancas, Contadurías Generales, Legajos 86-93.

We define all transactions by bankers who co-lend - either through joint loans or through sharing business partners - as network lending. Because this classification relies only on observable transactions through syndicated lending to the Crown, it constitutes a lower bound on the actual business and family relationships between bankers. ${ }^{50}$ Even under this restrictive definition, bankers in the network accounted for a disproportionate share of transactions and lending volume. There are only 27 families (out of 63 total) in the largest network we identified, but they accounted for $72 \%$ of principal extended to the king and for almost the same proportion of all transactions (see Table 4).

Over time, the size of the network is remarkably stable although its total share of lending declined slightly (Figure 8). Before the bankruptcy of 1575, network members accounted for $80 \%$ of lending; after it, for $67 \%$. There are two years when the king borrowed or transferred funds without any support of network members. In 1576, no banker was lending to the king, and the entire amount transacted consisted of pure transfers by nonnetwork members. In 1582, the king borrowed almost exclusively from the Fuggers, the most prominent family outside the network. The largest loan the Fuggers provided was for 1.3 million ducats in 1594 , a year in which the silver fleets did not sail.

\footnotetext{
${ }^{49}$ AGS, Contadurías Generales, Legajo 88. "Lo que por mi mandado se asienta y concierta con Francisco Spinola genovés sobre 30,000 escudos."

${ }^{50}$ To further illustrate how our definition understates the true extent of the network, we return to an example given previously. We reported that, as part of an asiento with Francisco Spinola, the king agreed to drop lawsuits against Lucián Centurión, Antonio Alvarez de Alcócer, and Manuel Caldera. These four bankers were clearly connected, but we do not consider them to be network members because Alcócer and Caldera never lent to the king in conjunction with other bankers.
} 


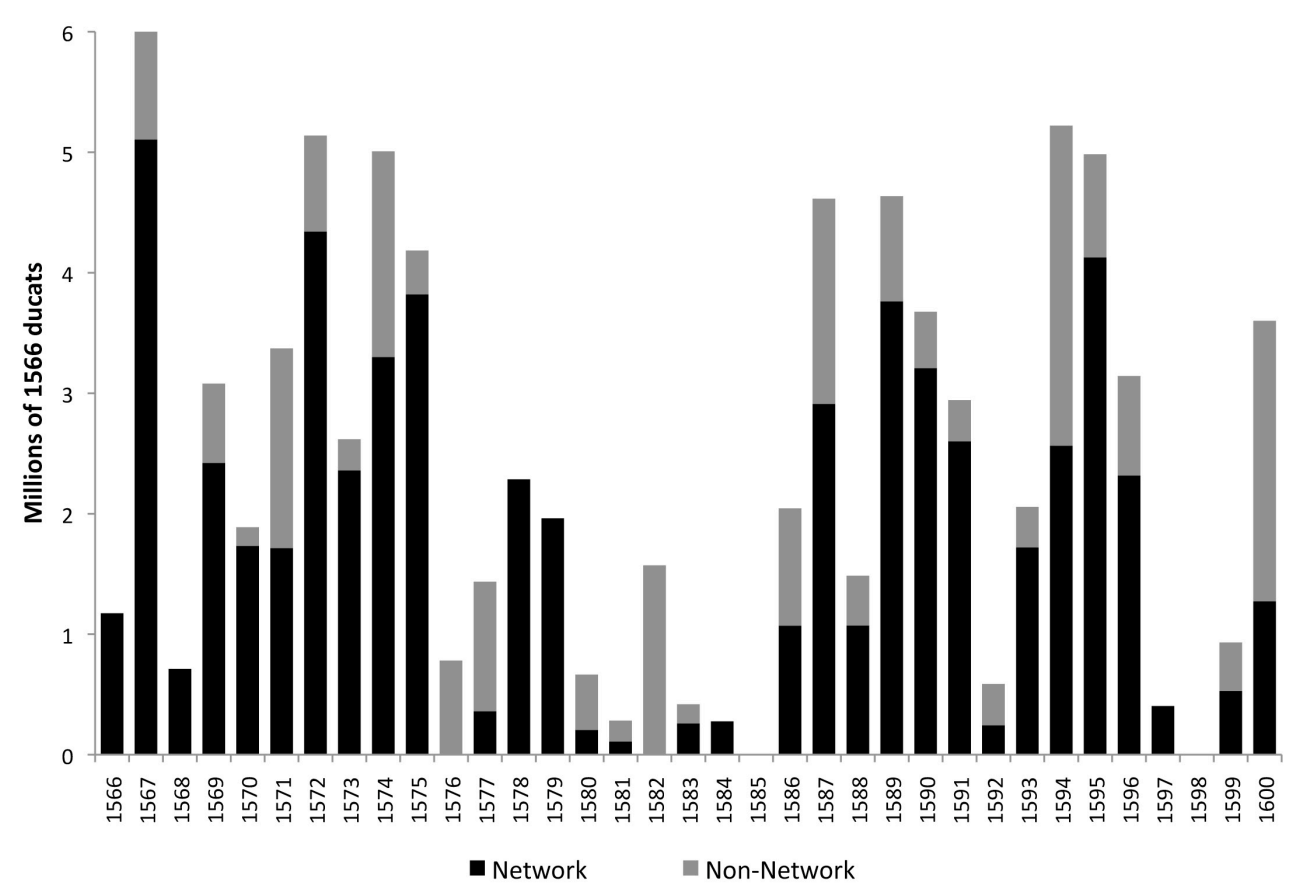

Figure 8: Lending by network members, 1566-1600

\section{Discussion}

In this section, we discuss the interpretation of our findings in the light of modern sovereign debt theory. We do so by focusing on how events unfold once the king defaults, and we argue that two factors interacted to make lending to him sustainable: the stability of the bankers' network and the incentives resulting from the presence of a dominant lender. The Genoese coordinated their actions closely. Because of his financing needs, Philip II could not do without the lending capacity of their network. Therefore, he eventually had to settle with the bankers that imposed a moratorium on him. ${ }^{51}$ This also made it unappealing for outsiders to start lending. We show the importance of lender market power in such a setting, along the lines of Kovrijnykh and Szentes (2007) and Wright (2002), and explain how this market power arose. In particular, we examine why there was no entry from new lenders and no disintegration of the dominant Genoese network. Our preferred interpretation highlights the importance of "cheat the cheater" enforcement (Kletzer and Wright 2000).

\footnotetext{
${ }^{51}$ Recent examples of historical network analysis include Jobst and Flandreau (2005) and Carlos, Neal, and Wandschneider (2007).
} 
.We argued before that two alternative smoothing mechanisms - depositing funds with a banker and long-term bond issuance - were not feasible; short-term borrowing was the only way to smooth expenditure. This gave bankers special market power. The position of the Genoese was further strengthened in that the king had to rely on intra-Genoese enforcement and deals with leading bankers in order to recover any funds when foreign bankers defaulted on his deposits. ${ }^{52}$ In addition, after 1560 the vast majority of long-dated bonds was issued with Genoese involvement. Castillo Pintado (1963, p. 49) argues that the bankers enjoyed a complete monopoly over transactions involving juros, thus controlling the king's access to long-term debt.

The crucial test of any coalition occurs in times of crisis. Genoese lenders experienced two crises during the sample period for which we have data: the defaults of 1575 and $1596 .{ }^{53}$ In both of these years, the king's need for cash was strong. Following the suspension of payments in 1575 , the Crown was desperate for funds. After the sack of Antwerp, the military situation in the Low Countries had deteriorated markedly. The Pacification of Ghent created a united front of Dutch provinces, while most Spanish troops refused to obey orders. It would take eight years and a large offensive just to recover the ground lost. Victory against the rebels, which had seemed within the Duke of Alba's grasp, began to look unlikely. Similarly, the threat of an English invasion in 1596 forced heavy spending to rebuild the fleet lost during the disastrous Armada expedition. During these episodes, numerous discussions took place between king and individual bankers from the network to explore the possibility of a side deal. None was concluded. Neither did any new lender enter to exploit the business opportunity represented by the default. We argue that a combination of social enforcement mechanisms (among the Genoese) and incentives (for the Genoese and all other potential lenders) were responsible for this outcome.

We first examine the stability of the Genoese coalition. During the debt renegotiations of 1576-1577 and 1596-1597, the king's representatives repeatedly tried to cut side deals with individual bankers. They mostly targeted the Spinola family, the

\footnotetext{
${ }_{53} \mathrm{Cf}$. the case cited in note 21 .

${ }^{53}$ The earlier defaults involved loans by the Fuggers and Welsers to Charles V. The settlements involved large transfers of physical assets - including mines, land, and tax farms - that are difficult to value. Furthermore, our series of asientos extends back only to 1566.
} 
monarchy's largest lender and the central actor in the network, as well as a few other large bankers. These attempts to split the coalition and combine fresh borrowing with preferential treatment on old debts did not succeed, even though the bankers clearly showed interest in the possibility of profiting from a side deal. In 1576, Lorenzo Spinola and Nicolao de Grimaldo engaged in protracted negotiations but failed to come to an agreement with the Crown (Lovett 1982, pp. 12-13; Carlos Morales 2008, p. 170). Eventually Nicolao de Grimaldo took part in the medio general. Although Lorenzo did not participate in the negotiations of the general settlement, his brother Agustín (a member of the family partnership) did. Overall, $93 \%$ of the loans in default were rescheduled by the general settlement. The remaining ones were contracts with small bankers that did not take part in the negotiations but were offered the same terms at a later date. In 1596, Ambrosio Spinola played a double game of negotiating on behalf of other network members while exploring a unilateral resumption under more favorable conditions for himself. At the same time, the Crown also tempted a small syndicate with special treatment in order to split them from the larger network. In the end, all bankers again settled on identical terms through a general agreement with the king (Sanz Ayán 2004, pp. 34-36). We do not know what, exactly, was on the minds of the Genoese banking families as they decided to maintain the moratorium, but it seems likely that the tight network of mutual commercial and other relationships kept individualopportunistic behavior in check.

By analyzing the behavior and writings of bankers outside the coalition, we can gain further insight into the motivations of both Genoese and other bankers for refusing side deals. The potential for bankers from outside the network lending to the king certainly existed. Throughout the second half of the 16th century, Philip borrowed from 36 families that did not belong to the Genoese network. These families constituted a "competitive fringe". The most important bankers outside the network were the Fuggers, who were responsible for about half the volume of transfers to Flanders during the 1575 suspension. In order to guarantee a flow of funds, the Crown continued to service the Fugger debt, specifically excluding them from the bankruptcy decree. The Royal advisor Dávalos de Sotomayor, lamenting the Crown's dire fiscal needs in 1576, said as much in a note to the king: "Your majesty has the inexcusable obligation . . . of paying back the 
Fuggers, who are not affected by the decree, somewhat less than two [million ducats]". 54 This illustrates the separation of the transfer and lending operations. By according preferential treatment to the Fuggers, the Crown was simply ensuring that they would not seize any cash meant to be transferred to Flanders. ${ }^{55}$

The Fuggers did try to benefit from the crisis in the Netherlands and the Crown's need for funds. Aware of the deteriorating military situation in Flanders, Tomás Miller (the Fugger agent in Spain) floated the idea of providing money for the troops. ${ }^{56}$ In the end, despite the enticing suggestion to provide funds for Philip's regiments in the Low Countries, there was no new loan by the Fuggers until 1580. What stopped the Fuggers from striking a bargain was fear of being defaulted upon immediately if they lent during the moratorium. The Fugger family back in Germany took a dim view of the prospects of any new loan as proposed by Miller. Hans Fugger wrote to his brother Marx complaining about the services they were already required to render to the king. ${ }^{57} \mathrm{He}$ emphasizes that Miller must be stopped lest the Fuggers be cheated and end up being included in the bankruptcy decree. ${ }^{58}$ If Miller is not stopped (and a new loan goes forward), then

the Spaniards will forever take advantage of us, they will suck us dry and exploit our position, and if we don't do everything they say, they will throw us mockingly, fraudulently into the decree, ${ }^{59}$ and . . mistreat us like the Genoese, whose fate we have before our own eyes. ${ }^{60}$

\footnotetext{
${ }^{54}$ Cited in Lovett (1982, p. 13).

55 There is one possible exception: the transfer of 100,000 ducats to Flanders in 1576 . The initial request by Garnica, one of the King's officials, was for 50,000 ducats to be advanced by the Crown with the rest to be paid from the next year's tax increase. But we have no evidence that the Fuggers actually lent any of this money.

${ }^{56}$ Lovett (1982, p. 13).

57 "Du siehst, daß sich von Tag zu Tag die Servitios, so wir dem Künig [von Spanien thun müeßen hauffen" (Karnehm 2003, p. 408-9).

58 "wirds ain grosse Notturfft erfordern, dem T[homas] Miller ain Bys einzulegen, wir khummen sonst burlando ins Decret." According to Karnehm (2003), "burlare" here means "fraudulently"; an alternative translation is "mockingly".

59 That is, apply the Royal Decree that imposed the payment moratorium on the lenders.

60 “die Sp[ani] er [werden sich] unser zu ewigen Zeitten . . . bedienen wellen, uns aussaugen, und nött[igen], wan wir dann nit jederzeit thun werden, was Sie wellen, so wirdt man uns das Decret fürwerffen, und sagen, man wöll uns darein schließen und tractieren wie die Genueser, wie dan schon vor Augen." Letter from Hans Fugger to Marx Fugger, 5 September 1576, cited in Karnehm (2003, pp. 408-9); emphasis added.
} 
What was on the mind of Hans Fugger is clear enough: if they offered fresh loans, the Fuggers might end up like the Genoese. He feared that the king would default on them, too, if they lent substantial funds. Thus, the Augsburg banking family decided to follow in lockstep the network's behavior. The Fuggers's concern is best described by what Kletzer and Wright (2000) call a "cheat the cheater" mechanism. Because they would not be able to satisfy all of the king's demands, the Fuggers saw it as a virtual certainty that they would be cheated and defaulted upon. The reason they could not satisfy every possible demand by Philip is also clear: his smoothing needs were simply too large. Eventually the Castilian king would have to settle with the Genoese, and the Fuggers would then lose everything. There is every reason to believe that the same logic that kept the Fuggers from lending was also a major constraint on the behavior of the Genoese banking families who might have been tempted by the king's offers. Thus, the power of the "cheat the cheater" mechanism stemmed from the market power of the existing Genoese coalition, and it deterred insider defections as well as incursions from outsiders. As in Wright (2002), syndicated lending is a key factor sustaining the market power of the dominant banker coalition.

\section{Conclusions}

Philip II of Spain accumulated towering debts during his long reign. He also defaulted four times on his creditors yet without losing access to funds. In this paper, we examine what made lending to him sustainable. As noted by Bulow and Rogoff (1989a), in the absence of potential entrants, lending can occur even if no penalties are available. Philip II had access to more than one lender, and he borrowed heavily. Using a new data set collected from the General Archives in Simancas, we document a unique way in which his bankers overcame enforcement and collective action problems - namely, lending in overlapping syndicates. By structuring incentives through a "private order institution" (Greif 2006), the largest and most important bankers acted as if they were a single financial entity, a "lenders' coalition". This effective coordination between lenders gave the coalition substantial market power vis-à-vis the king; in effect, Philip II had access to only one lender. Thus, even at the dawn of sovereign borrowing, we find evidence that is broadly supportive of a class of models emphasizing the importance of reputational 
mechanisms. As in Eaton and Gersovitz (1981), the importance of coping with volatile revenues is key. In the spirit of recent work emphasizing market power (Wright 2002; Kovrijnykh and Szentes 2007), we have presented evidence that bankers found ways to coordinate their actions.

The crucial test for our hypothesis is the default of 1575 . In contrast to the argument in Conklin (1998), we find little evidence that lenders had ways to sanction Philip II. A transfer stop that cut funding for the troops in Flanders, as identified by Conklin, never materialized; the Fuggers and other bankers continued to offer transfer services as long as they were paid up front. Neither was there a mass exodus of lenders following the defaults. Contrary to the argument in Braudel (1966), banker turnover was minimal. No new lenders emerged during the moratorium imposed by the Genoese coalition.

In sum, neither new nor existing lenders undermined the moratorium's effectiveness. The reason is that doing so was unlikely to make money. The king's borrowing needs were so high that he would eventually have to settle with the coalition. Conditional on this outcome being viewed as inevitable, no single banker had an incentive to lend. Because the Genoese acted in unison, any lender who had offered funds to Philip II during the moratorium would most likely be cheated, in line with the predictions of Kletzer and Wright (2000). We thus find support for theories of sovereign lending that view lender coordination and market power as crucial.

Lending occurred under conditions of anarchy, with neither side being able to make commitments. What underpinned the durability of lending relationships was the fact that Philip's defaults were excusable. An unfortunate confluence of military necessities, combined with weak tax and silver revenues, made reschedulings necessary. In the spirit of Grossman and van Huyck (1988), we interpret the repeated defaults and resumptions of lending as largely anticipated events. Once the situation improved, bankers and king agreed on a substantial haircut that allowed the Crown to escape debt overhang. ${ }^{61}$ Why established lenders in the Genoese coalition repeatedly agreed to debt reductions and a resumption of lending is also probably best explained by the market power derived from the group's cohesion. This ensured that, even after earlier debts had

\footnotetext{
${ }^{61}$ This is in line with the predictions of Kovrijnykh and Szentes (2007).
} 
been reduced, future profits would be ample. Far from indicating banker irrationality and the importance of lender sentiment, the boom-and-bust cycles of the 16th-century Spanish monarchy reflect the efficiency and flexibility of private-order institutional arrangements. ${ }^{62}$

\footnotetext{
${ }^{62}$ For a broader perspective, see Greif $(1998 ; 2006)$.
} 


\section{References}

Primary Sources

España. Ministerio de Cultura. Archivo General de Simancas.

Sección "Contadurías Generales".

Sección "Concejo y Juntas de Hacienda".

Secondary Sources

Acemoglu, D., S. Johnson, and J. Robinson. 2005. The rise of Europe: Atlantic trade, institutional change, and economic growth. American Economic Review 95 (3):546-579.

Alvarez Nogal, Carlos. 2003. The Role of Institutions to Solve Sovereign Debt Problems: The Spanish Monarchy's Credit (1516-1665). Universidad Carlos III working paper 03-08.

Alvarez Nogal, Carlos, and Leandro Prados de la Escosura. 2007. The Decline of Spain (1500-1850): Conjectural Estimates. European Review of Economic History 11 (3):319-366.

Artola, Miguel. 1982. La Hacienda del Antiguo Régimen. Madrid: Alianza.

Braudel, Fernand. 1966. The Mediterranean and the Mediterranean World in the Age of Philip II. 2nd revised ed. Glasgow: William Colins \& Sons.

Bulow, Jeremy, and Kenneth Rogoff. 1989a. A Constant Recontracting Model of Sovereign Debt. Journal of Political Economy 97 1:155-78.

. 1989b. Sovereign Debt: Is to Forgive to Forget? American Economic Review 79 1:43-50.

Carande, Ramón. 1987. Carlos Vy sus banqueros. 3. ed. 3 vols. Barcelona: Crítica.

Carlos, Ann, Larry Neal, and Kirsten Wandschneider. 2007. Networks, Brokers and the Market for Bank of England Shares: Strength of Weak Ties. U Colorado working paper

Carlos Morales, Carlos Javier de. 2008. Felipe II: El Imperio en Bancarrota. Madrid: Dilema.

Castillo Pintado, Alvaro. 1963. Los juros de Castilla. Apogeo y fin de un instrumento de crédito. Hispania 23 (89):43-70.

Cole, Harold L., and Patrick J. Kehoe. 1995. The Role of Institutions in Reputation Models of Sovereign Debt. Journal of Monetary Economics 35 1:45-64.

Conklin, James. 1998. The Theory of Sovereign Debt and Spain under Philip II. Journal of Political Economy 106 3:483-513.

Drelichman, Mauricio, and Hans-Joachim Voth. 2007. The Sustainable Debts of Philip II: Revenues, Expenditures and Primary Surplus in Habsburg Spain, 1560-1598.

UBC Working Paper. 
Eaton, Jonathan, and Raquel Fernandez. 1995. Sovereign Debt. NBER Working Paper 5131.

Eaton, Jonathan, and Mark Gersovitz. 1981. Debt with Potential Repudiation: Theoretical and Empirical Analysis. Review of Economic Studies 48 2:289-309.

Esteves, Rui. 2006. Quis custodiet quem? Sovereign Debt and Bondholders' Protection Before 1914. Oxford University Working Paper.

Fernandez, Raquel, and Robert W. Rosenthal. 1990. Strategic Models of Sovereign Debt Renegotiations. Review of Economic Studies 57:331-349.

Goris, J. A. 1925. Étude Sur Les Colonies Marchandes Mériodinales (Portugais, Espagnols, Italiens) À Anvers De 1488- À 1567. Contribution À L'histoire Des Débuts Du Capitalisme Moderne. Louvain: Librairie Universitaire Vystpruyst.

Greif, Avner. 1993. Contract Enforceability and Economic Institutions in Early Trade: The Maghribi Traders Coalition. American Economic Review 83:525-548.

- 2006. Institutions and the path to the modern economy: lessons from medieval trade, Political economy of institutions and decisions. Cambridge ; New York: Cambridge University Press.

Grossman, Herschel I., and John B. Van Huyck. 1988. Sovereign Debt as a Contingent Claim: Excusable Default, Repudiation, and Reputation. American Economic Review 78:1088-1097.

Jobst, Clemens, and Marc Flandreau. 2005. The Ties that Divide: A Network Analysis of the International Monetary System, 1890-1910. The Journal of Economic History 65 (4):977-1007.

Karnehm, Ch. 2003. Die Korrespondenz Hans Fuggers von 1566 bis 1594. Regesten der Kopierbücher aus dem Fuggerarchiv 1574-1581. Munich: Quellen zur Neueren Geschichte Bayerns.

Kletzer, Kenneth M., and Brian D. Wright. 2000. Sovereign Debt as Intertemporal Barter. American Economic Review 90 3:621-39.

Kovrijnykh, Natalia, and Balázs Szentes. 2007. Equilibrium Default Cycles. Journal of Political Economy 115 (3):403-446.

Lapeyre, Henri. 1953. Simón Ruiz et les "asientos" de Philippe II. Paris: Librairie Armand Colin.

Lovett, A. W. 1980. The Castilian Bankruptcy of 1575. The Historical Journal 23:899911.

1982. The General Settlement of 1577: An Aspect of Spanish Finance in the Early Modern Period. The Historical Journal 25 (1):1-22.

Mitchener, Kris James, and Marc D. Weidenmier. 2005. Supersanctions and Sovereign Debt Repayment. In NBER Working Paper Series.

Parker, Geoffrey. 1998. The Grand Strategy of Philip II. New Haven and London: Yale University Press. 
Reinhart, Carmen M., and Kenneth Rogoff. 2008. This Time is Different: A Panoramic View of Eight Centuries of Financial Crises. In NBER Working Papers 13882.

Reinhart, Carmen M., Kenneth S. Rogoff, and Miguel A. Savastano. 2003. Debt Intolerance. Brookings Papers on Economic Activity 2003 (1):1-74.

Sanz Ayán, Carmen. 2004. Estado, monarquía y finanzas. Estudios de historia financiera en tiempos de los Austrias. Madrid: Centro de estudios políticos y constitucionales.

Toboso Sánchez, Pilar. 1987. La deuda pública castellana durante el Antiguo Régimen (juros) y su liquidación en el siglo XIX. Madrid: Instituto de Estudios Fiscales.

Tomz, Michael. 2007. Reputation and International Cooperation. Sovereign Debt across Three Centuries. Princeton: Princeton University Press.

Ulloa, Modesto. 1977. La hacienda real de Castilla en el reinado de Felipe II. 2nd ed. Madrid: Fundación Universitaria Española, Seminario Cisneros.

Vázquez de Prada, Valentín. 1960. Lettres Marchandes d'Anvers. Paris: S.E.V.P.E.N.

Wright, Mark. 2002. Reputations and Sovereign Debt. Stanford Working Paper. 


\section{Appendix}

Table A1: Value of repeat lending (millions of constant ducats)

\begin{tabular}{|c|c|c|c|}
\hline Year & Repeat lenders & Sporadic lenders & $\%$ Repeat lending \\
\hline 1569 & 2.642 & 0.275 & $90.6 \%$ \\
\hline 1570 & 1.851 & 0.036 & $98.1 \%$ \\
\hline 1571 & 2.386 & 0.986 & $70.8 \%$ \\
\hline 1572 & 4.374 & 0.764 & $85.1 \%$ \\
\hline 1573 & 2.618 & 0.000 & $100.0 \%$ \\
\hline 1574 & 5.007 & 0.000 & $100.0 \%$ \\
\hline 1575 & 3.928 & 0.256 & $93.9 \%$ \\
\hline 1576 & 0.781 & 0.000 & $100.0 \%$ \\
\hline 1577 & 1.436 & 0.000 & $100.0 \%$ \\
\hline 1578 & 2.286 & 0.000 & $100.0 \%$ \\
\hline 1579 & 1.962 & 0.000 & $100.0 \%$ \\
\hline 1580 & 0.459 & 0.205 & $69.2 \%$ \\
\hline 1581 & 0.152 & 0.130 & $53.9 \%$ \\
\hline 1582 & 0.954 & 0.617 & $60.7 \%$ \\
\hline 1583 & 0.238 & 0.181 & $56.8 \%$ \\
\hline 1584 & 0.000 & 0.277 & $0.0 \%$ \\
\hline 1585 & 0.000 & 0.000 & - \\
\hline 1586 & 1.644 & 0.401 & $80.4 \%$ \\
\hline 1587 & 4.348 & 0.266 & $94.2 \%$ \\
\hline 1588 & 1.276 & 0.209 & $85.9 \%$ \\
\hline 1589 & 4.406 & 0.229 & $95.1 \%$ \\
\hline 1590 & 3.584 & 0.092 & $97.5 \%$ \\
\hline 1591 & 2.567 & 0.376 & $87.2 \%$ \\
\hline 1592 & 0.587 & 0.000 & $100.0 \%$ \\
\hline 1593 & 1.870 & 0.186 & $90.9 \%$ \\
\hline 1594 & 3.418 & 1.804 & $65.5 \%$ \\
\hline 1595 & 4.023 & 0.960 & $80.7 \%$ \\
\hline 1596 & 2.728 & 0.414 & $86.8 \%$ \\
\hline 1597 & 0.303 & 0.101 & $75.0 \%$ \\
\hline 1598 & 0.000 & 0.000 & - \\
\hline 1599 & 0.529 & 0.402 & $56.8 \%$ \\
\hline 1600 & 1.764 & 1.837 & $49.0 \%$ \\
\hline Total & 64.121 & 11.004 & $85.4 \%$ \\
\hline
\end{tabular}

Source: Archivo General de Simancas, Contadurías Generales, Legajos 86-93. 


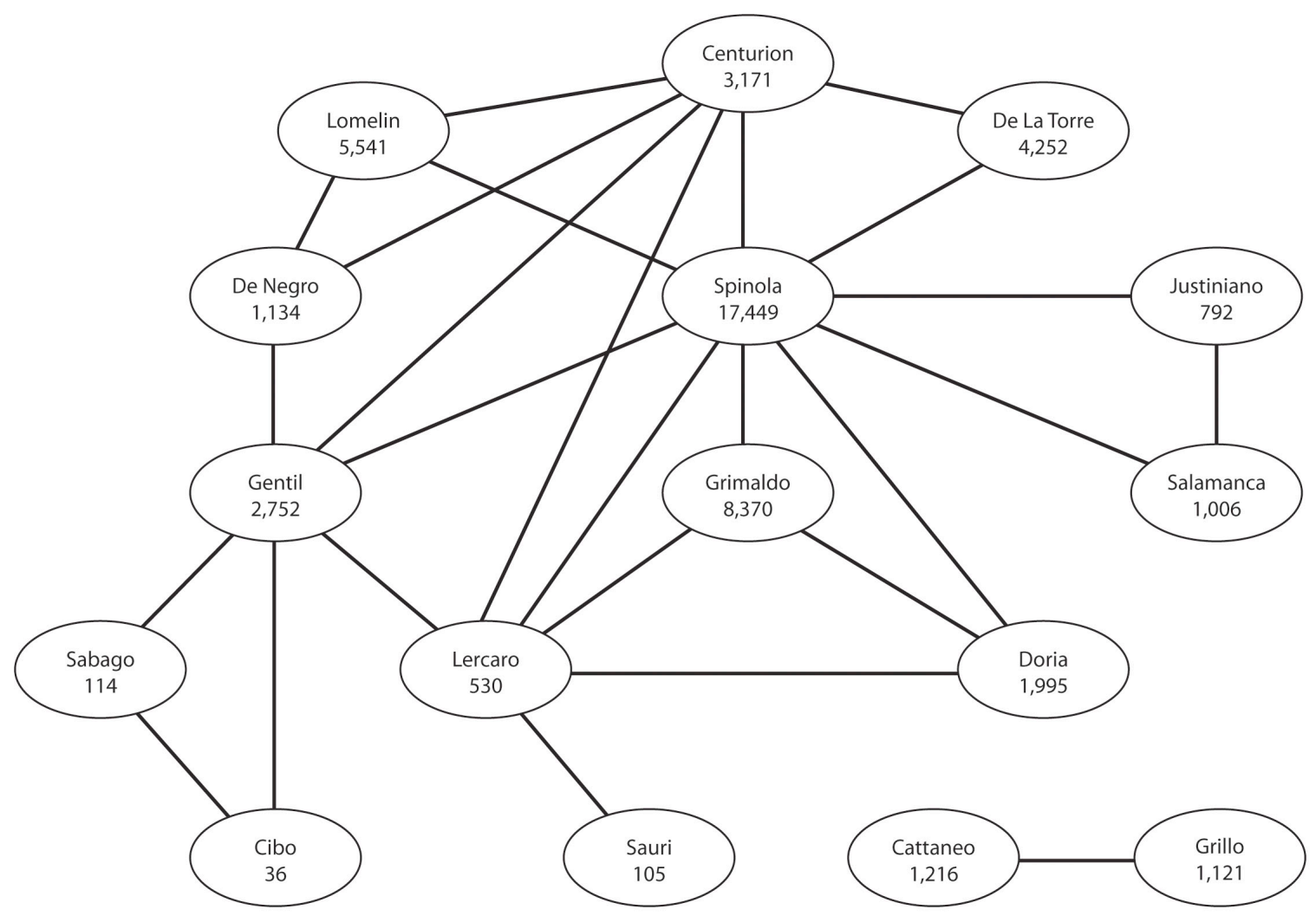

Figure A1: Structure of the network based on transactions prior to 1575 only 